\title{
Coproduction of Health Care for Indigenous Women: Evaluating a Medical Intervention in the Great Chaco Region*
}

Presenter and corresponding author:

\author{
Tulia G. Falleti ${ }^{+}$ \\ Class of 1965 Endowed Term Professor of Political Science, \\ Director of the Latin American and Latinx Studies Program \\ Senior Fellow Leonard Davis Institute of Health Economics \\ University of Pennsylvania \\ falleti@,upenn.edu
}

Co-authors:

\section{Santiago L. Cunial ${ }^{+}$, Selene Bonczok Sotelo ${ }^{+}$, and Favio Crudo ${ }^{++}$}

\author{
Version: August 26, 2020 \\ Paper prepared for presentation at the 2020 American Political Science Association annual \\ meeting, September 12.
}

Please do not cite this paper without prior email authorization from corresponding author.

Comments are very welcome

\footnotetext{
* Falleti, Cunial, and Sotelo are grateful to Dr. Alejandro Krolewiecki for introducing them to the ADESAR/Mundo Sano team and to the Center for Undergraduate Research and Fellowships (CURF) and the Latin American and Latinx Studies (LALS) Program of the University of Pennsylvania for funding. The paper benefited from participants' comments at the $4^{\text {th }}$ Mundo Sano research meeting; the Lansing B. Lee, Jr. Seminar in Global Politics at the University of Virginia; the Department of Political Science Seminar at University of Texas-Austin; and the David Rockefeller Center at Harvard University, where it was presented.

${ }^{+}$University of Pennsylvania

${ }^{++}$ADESAR
} 


\begin{abstract}
:
Coproduction between state and civil society in the delivery of public goods and services raises a host of questions that go from capture of the state, to cooptation of civil society, and efficiencies or accountability in the delivery of public services. Moreover, when this cooperation focuses on vulnerable and historically marginalized indigenous populations, ethical concerns arise about intercultural sensitive care. We tackle these thorny issues by analyzing a recent collaboration among the states of Argentina, Bolivia, and Paraguay and two health care non-governmental organizations (NGOs) that provide prenatal care to women in the Great Chaco region, where a majority of the population is indigenous and maternal and infant mortality have been historically high. Based on participant observation and in-depth interviews, we analyze the opinions of public health care providers regarding the NGOs' intervention. In particular, we focus on their opinions and evidence regarding the extent to which there is complementarity and/or embeddedness between the state and the NGOs, which we evaluate along four dimensions: 1) patients' access to health care, 2) diagnostic and treatment of patients, 3) human resources in the health care sector, and 4) financial resources in the health care sector. We argue this intervention is a valuable strategy to significantly improve access and delivery of health care to pregnant women and to attend neglected diseases. We also raise concerns about institutional racism and the absence of an intercultural approach to health care. The paper will contribute to the literatures on coproduction and on the provision of public services, health care in particular, to indigenous populations.
\end{abstract}

Keywords: coproduction, indigenous communities, Wichí, prenatal care, Chagas, Great Chaco. 


\section{Introduction}

In late January 2020, as the World Health Organization declared a global health emergency due to the outbreak of a new coronavirus originated in Wuhan, China; on the opposite side of the world, in the Argentine province of Salta, the government declared a socio-sanitary emergency for its departments of Rivadavia, Orán, and San Martín. ${ }^{1}$ This socio-sanitary emergency originated in the fact that in less than a month, six children under the age of 5 and a mother in childbirth had died in the east of the province. Five of the children were Wichi, the majority indigenous ethnic group of the eastern part of Salta and of the Great Chaco region. At least three of the children were malnourished, and all of them presented symptoms of dehydration and diarrhea, due to the lack of clean water.

In this paper, we analyze a medical intervention taking place in that region of Salta and in the neighboring localities of Bolivia and Paraguay, in the tri-border area of the Great Chaco region, since mid-2018. As we describe below, this is a collaboration between two Argentine health nongovernmental organizations (NGOs), a private university, and the provincial health authorities of the three countries. We aim to analyze this partnership from the point of view of coproduction, a concept developed by Elinor Ostrom and her research teams to bridge the divide between state and civil society and between theories of the state and the economy. What do we learn about this medical intervention once this concept is applied? What lessons can we draw that may help improve the socio-sanitary situation in the eastern part of the Salta province? What lessons can we more generally draw regarding the provision of health care to indigenous populations?

\footnotetext{
${ }^{1}$ New York Times, "W.H.O. Declares Global Emergency as Wuhan Coronavirus Spreads" January 31, 2020, https://www.nytimes.com/2020/01/30/health/coronavirus-world-health-organization.html; and Pagina 12/Salta 12, "El Gobierno declaró la emergencia socio sanitaria por 180 días" January 29, 2020, https://www.pagina12.com.ar/244282-el-gobierno-declaro-la-emergencia-socio-sanitaria-por-180-di; Página 12/Salta 12; last accessed 01/31/20.
} 
In the recent literature on state-society relations, coproduction in the delivery of public goods and services occupies a prominent place. Partnerships between state and civil society are conceptualized not only as vehicles for easier enforcement of state rules and regulations (Amengual and Dargent 2020), but also as venues to increase civil society participation and the legitimacy of state institutions (Goodwin 2019; Ostrom 1996). However, this mode of articulation between state and civil society opens up a host of questions that go from capture of the state or public resources by private actors and businesses, cooptation of civil society groups or individuals by public officials, the degree of efficiency in the delivery of public services that may become ad hoc, to the standards of accountability of NGOs or groups that are not part of the state, among others. Moreover, and also related to the issue of accountability, when coproduction takes place toward vulnerable and historically marginalized populations, ethical concerns may emerge surrounding the partnership between state and intermediary civil society agents that may not undergo the same level of training or supervision than state bureaucrats.

In this article, we tackle the thorny problem of coproduction by analyzing a recent collaboration among the states of Argentina, Bolivia, and Paraguay, with two Argentine health care NGOs: Asociación para el Desarrollo Sanitario Regional (or ADESAR) and Mundo Sano, and the advanced medical students of the Instituto Universitario del Hospital Italiano to deliver health care to pregnant women in remote villages near their tri-border area, in the Great Chaco region, where the majority of the population is indigenous and maternal and infant mortality have been historically high. Based on the results of the medical intervention from June 2018 to October 2019, participant observation and in-depth interviews carried out in August of 2019, we analyze coproduction, in particular, through the lens of state agents, including public health care providers (doctors, nurses, and sanitary agents), public health sector officials of the local and provincial 
levels, and other state bureaucrats. How do they evaluate the NGOs intervention? What is the relationship between state agents and NGO doctors like? As we analyze the interviews, we focus on the issues of complementarity and embeddedness in coproduction, which we evaluate along four dimensions: 1) patients access to health care, 2) diagnostic and treatment of patients, 3) human resources in the health care sector, and 4) financial resources in the health care sector.

We argue that coproduction is a valuable strategy to attend neglected diseases and that mobile health care can significantly improve access and delivery of health care for pregnant women. However, as we will show, there is significantly more complementarity than embeddedness in this medical intervention. We also raise concerns about institutional racism and the absence of an intercultural approach to health care. Hence, our paper aims to contribute to the literatures on coproduction and provision of public health care to indigenous populations.

The paper is organized as follows. Section 2 discusses the literature on coproduction of state - civil society, particularly as it applies to the health care sector and to medical interventions with NGOs as intermediary agents between the state on the one hand and the patients on the other. Section 3 presents the environmental, socioeconomic, and ethnic context in which the medical intervention takes place. Section 4 describes the medical intervention. Section 5 presents the opinion of state agents regarding coproduction with the NGOs and draws from the most recent treatment and diagnostic results of the intervention as well as our participatory observation to evaluate levels of complementarity and embeddedness along of the intervention. The last section concludes.

\section{Literature Review and Theory}


At least since Ostrom (1996) proposed to "cross the great divide" (in fact, the double divide between states and societies as well as between states and markets), political scientists, economists, and healthcare scholars alike have been studying processes of "coproduction." According to Ostrom, coproduction is "the process through which inputs used to produce a good or service are contributed by individuals who not 'in' the same organization ... Coproduction-she addsimplies that citizens can play an active role in producing public goods and services of consequence to them." $(1996,1073)$ In other words, coproduction presupposes the active participant role of citizens, and when successful, the state reveals its capacity to be "permeable" without being captured and to capitalize on societal input. To Ostrom, coproduction of many goods and services is crucial for achieving higher levels of welfare in developing countries, where public resources are insufficient to meet people's needs and where the cost of opportunity of citizens' participation in the provision of a good or service is lower than the cost of the government producing that same output (1996, 1080-1083). Or as she puts it: "Many poor regions and neighborhoods are characterized by severe underutilization of the knowledge, skills, and time of residents - which means that the opportunity costs of devoting these inputs to the creation of valued public outputs are low. Obtaining better infrastructure and services generates very high benefits." (Ostrom 1996, 1080). Of course, this conceptualization of coproduction begs the question of whether the resulting public services and goods in poor neighborhoods or regions (or countries, for that matter) will be of the same quality, for instance, that those provided in wealthier neighborhoods or regions (or countries). The successful example of coproduction that Ostrom cites in her World Development

\footnotetext{
${ }^{2}$ Elinor and Vincent Ostrom and their collaborators first developed the concept of coproduction at a Workshop in Political Theory and Policy Analysis in the late 1970s (Ostrom 1996, 1078-9). However, it was after the 1996 symposium in the World Development journal that the concept was significantly embraced by social scientists. See Goodwin (2019) for an excellent analysis of the definition and evolution of the concept of coproduction as applied to the provision of public goods and services.
} 
article, for instance, regards the creation of a "condominial system" of water infrastructure in the city of Recife, in the northeast of Brazil during the 1980s. Instead of building the sanitation system with large cast-iron pipes sunk deep under urban streets, the condominium system meant smaller feeder lines that could go through sidewalks or even inside private properties and that were built with input and labor from neighbors, and also maintained by them (Ostrom 1996, 1074). Other scholars interpret these type of self-help programs, such as it was the case of the self-construction of workers' housing with materials and funding from the Alliance for Progress in the 1960s in Latin American cities, in a more critical light and as the ideological and material roots of the austerity policies and the imbrication of state and corporate business interests that became paramount during the neoliberal era (Offner 2019).

However, as Peter Evans (1996) notes, in his introduction and conclusion to the set of articles published alongside Ostrom's 1996 article (see World Development, Volume 24, No. 6), successful coproduction implies both complementarity and embeddedness between state and society. Whereas the issue of complementarity was present in Ostrom's analysis (for instance, in the form of her proposed combination of production functions of government and citizens), the issue of embeddedness was largely missing, except perhaps for her reference to the fact that bureaucrats needed "to work effectively in problem-solving activities with citizens." (Ostrom 1996, 1083) Given his prior scholarship (Evans 1995), Evans addresses the issue of embeddedness in coproduction head-on. For him, successful coproduction or, as he calls it, synergy between state and civil society means that "civic engagement strengthens state institutions and effective state institutions create an environment in which civic engagement is more likely to thrive" (Evans 1996b, 1034). Thus, Evans (1996a, 1996b) identifies two forms of synergy. First, synergy canas Ostrom had noted--depend on complementarity: the "healthy relationship between public and 
private sphere" (1996b, 1035), or the "mutually supportive relationships between public and private actors ... [which] suggests a clear division of labor, based on the contrasting properties of public and private institutions" (1996a, 1120). Second, synergy can be based on "embeddedness," when informal societal networks and trust span the public-private divide (1996a, 1035-36). Moreover, he acknowledges that complementarity and embeddedness can, in turn, be mutually supportive and play a developmental role (1996a, 1120).

Since that symposium on World Development, coproduction has been amply studied, both in public health (e.g., Batalden et al. 2016) as well as in economics (e.g., Austen and Jefferson 2019; Deserrano et al. 2019; Kremer and Clingingsmith 2007) and political science (e.g., Amengual 2016; Falleti and Cunial 2018). Yet, most of the literature centers on the relationship between states and individual citizens (or as called in the early studies, "clients"). Studies that analyze the triangular relationships between states, intermediate civil society collective actors such as non-governmental organizations (or NGOs), and individual citizens are rarer (for an example, see Deserrano et al 2019). Our paper aims to fill in this vacuum in the coproduction literature by analyzing the relationship between states, NGOs for the delivery of health care services, and patients. Furthermore, our study sheds light on an area of health care and public policy very little researched in political science as is the delivery of health care to indigenous populations.

\section{Context}

The Great Chaco is a tropical dry forest, the largest in the world, located east of the Andes and west of the Paraguay river. It occupies the center-north of Argentina and the neighboring parts of Bolivia and Paraguay. ${ }^{3}$ The word chaco comes from the Quechua chaku, meaning "hunting

\footnotetext{
${ }^{3}$ Hear Erika Cuellar, a biodiversity Conservation trainer, giving a TED talk about the Great Chaco region and her conservation work there: https://www.youtube.com/watch? $\mathrm{v}=\mathrm{BmUV} 5 \mathrm{xuUfQk}$.
} 
land," testament to the region's wildlife, which supported indigenous peoples (the various groups making up the Guaycurú family) long before European settlers arrived to the area. The region also contains an array of wildlife and landscapes, from dry mountain grasslands, in the western dry Chaco, to woody forests and palm stands in the eastern, most humid, part (see Map 1). ${ }^{4}$ The area has historically had high rates of maternal and infant mortality. ${ }^{5}$ Chagas disease is endemic and closely linked to poverty in the region. ${ }^{6}$

Map 1 about here

The ADESAR/Mundo Sano medical intervention takes place in the tri-border of the Great Chaco region, in the area where Argentina, Bolivia, and Paraguay meet. The most granular comparable socioeconomic and demographic data available is at the department (Argentina and Paraguay) and municipal (Bolivia) level, and is presented in Table 1.

Table 1 about here

The majority of the inhabitants in the localities of the intervention belong to indigenous groups. In Argentina, they are mostly Wichi and Chorote. In Bolivia, there is a branch of the Wichi called Weennhayek, and in Paraguay, they are mostly Guarani. There are also in the tri-border area

\footnotetext{
${ }^{4}$ See region's fauna and flora description in https://www.worldwildlife.org/magazine/issues/summer2018/articles/exploring-the-gran-chaco, last accessed 01/22/20.

${ }^{5}$ In 2015, the province of Salta (part of which is in the Argentine Chaco) had the highest rate of maternal mortality in the country with 8.1 per 10,000 live births (Source: https://www.paho.org/salud-en-lasamericas-2017/?page id=83, last accessed 01/22/20). In the first half of January of 2020, the hottest month of the year, when temperatures in the Great Chaco reach 45 degrees Celsius (113F), at least three Wich $i$ infants died in the Great Chaco region of Salta due to malnutrition and dehydration. These events were covered by the Argentine national press and prompted an emergency visit to the area by the National Minister of Social Development, Daniel Arroyo and the Governor of Salta Gustavo Saenz, which among other places visited the Hospital of Santa Victoria Este (see Pagina 12, "Ahora la provinica quiere relevar si hay niños Wichí en riesgo," January 15, 2020, and related articles published in Pagina 12 during that week). Just days later two more Wichí children (under the age of 3) died due to lack of access to proper medical care (see La Gaceta de Salta, https://www.lagacetasalta.com.ar/nota/130940/sociedad/nino-Wichíapenas-paso-ano-vida-murio-hambre.html, https://www.lagacetasalta.com.ar/nota/131712/actualidad/fallece-bebe-Wichí-8-meses-tartagal.html).

${ }^{6}$ In 2014, infection by Trypanosoma cruzi affected $2.5 \%$ of pregnant women in Argentina.
} 
indigenous members of the Churupi, Manjui, and Nebaclé, among other ethnicities. Most of the indigenous population, and particularly the majoritarian Wichi group speak their own language at home as their first language. Men of these indigenous communities, particularly those who live in proximity of the Pilcomayo river, practice traditional fishing through a method called pesca de tijeras. $^{7}$ Women and men in these communities weave fishing nets, baskets, textiles, and ornaments with the fiber extracted from a local plant called chaguar. ${ }^{8}$

In Argentina, the ADESAR/Mundo Sano team intervenes in the localities of Santa Victoria Este (SVE) and Alto La Sierra (ALS) in the department of Rivadavia, in the western part of the Salta province, close to the border with the Formosa province. In Santa Victoria Este, the health care team sees patients in the Public Hospital of Santa Victoria Este, and from that locality travels, during the first week of the intervention, to the Health Posts in La Puntana, ${ }^{9}$ Monte Carmelo, Santa Maria, Misión La Paz, and Vertiente. In ALS, the medical team sees patients in the Hospital of ALS, and from this locality travels, during the second week of the intervention, to see patients in parajes or villages such El Desemboque, La Esperanza, La Soledad, La Misión, Las Avispas, Ensenadita, San Bernardo, Vertiente Chica, el Toro, Pozo El Mulato y El Bravo, among others (see Map 2).

\footnotetext{
${ }^{7}$ It consists of fishing with nets that are attached to two adjoining sticks, in the shallow part of the river at a depth that is up to about waist height. This video shows the practice of pesca de tijera in the Pilcomayo river, most likely on the Argentine side: https://www.youtube.com/watch? $\mathrm{v}=\mathrm{N}$ b7i-sFI0I, last accessed on $01 / 24 / 20$. Nowadays the so-called skirt-net (round-shaped and pulled by a string) is also used. This video is highly illustrative of the fishing practice on the Bolivian side of the Pilcomayo, and many ways of cooking the sábalo or tarpon fish: https://www.youtube.com/watch? $\mathrm{v}=\mathrm{bk} 7 \mathrm{PuXkzO} 4 \mathrm{o}$, last accessed on $01 / 24 / 20$.

${ }^{8}$ In a non-representative survey we conducted of pregnant women who were treated by the medical team during the August of 2019 visit ( $\mathrm{N}=103)$, we found that only $20 \%$ of them spoke solely Spanish at home, whereas at least $46 \%$ spoke Wichi at home (See Appendix, Figure A1). Fifty seven percent of the women surveyed were recipients of a social welfare program--in Argentina, that number ascended to 60.3\% (see Figure A2). In terms of education, only $16 \%$ of the pregnant women in our sample had finished high school, and $34 \%$ had less than primary school (see Figure A3).

${ }^{9}$ A majority Wichi settlement of approximately 1,000 people or 80 families (fieldnotes, August 5, 2019)
} 
Map 2 about here

In Bolivia, the intervention visits the localities Crevaux and D'Orbigny, in the municipality of Yacuiba, in the province of Gran Chaco, department of Tarija, over the course of one day during the first week of the intervention. Both of these localities are within one-to-two-hour drive from the border with Argentina, on the north side of the Pilcomayo river. Also, north of Pilcomayo are the Paraguayan towns of Pozo Hondo and San Agustín, in the department of Boquerón, where the intervention sees patients over the course of another day during the first week of the intervention.

Some of these parajes consist of a small group of families. Sometimes it is one extended family, as in the case of Las Avispas, in the proximity of ALS. In these parajes, families live in very precarious dwellings, such as wood sticks that hold a plastic tarp or fabric, which are disassembled as the family moves in the region (or monte) collecting firewood (or leña) for sale (see Figure 1). They always have a fire on, which they use both for warming up and cooking. In Argentina, women usually carry their and their children's national identity cards with them (in the waist of their skirts or tacked away in a plastic bag in a high post or beam in the house), and most of the children and adults are registered as this is a precondition for receipt of social welfare. Some of the inhabitants of these parajes are transhumant indigenous families, who have a deep distrust of western medicine, doctors, and the public health care system. For instance, during the August 2019 visit, some women in the most isolated and remote parajes would hide from the doctors and walk into the monte, away from their dwellings and the dirt road travelled by the doctors of the intervention, fearing treatment or derivations to the hospital. The inhabitants of these parajes mostly travel by bare foot (very few have a motorcycle). Thus, the footprints of the women bare feet, most times accompanied by the footprint of children, could be seeing in the dirt, as doctors tried to find them to do follow up visits. For the indigenous inhabitants of the remote parajes of 
the monte, especially those who live in transhumant conditions, a derivation to the hospital entails facing a series of challenges. First, the ambulance must take them there, which is not always possible, as during the rainy season, due to road conditions and availability of an ambulance. ${ }^{10}$ Second, it is customary for the whole family to accompany the member who is being hospitalized, thus a hospitalization can significantly disrupt the family's daily life. Third, while in the hospital, indigenous Wichi are penalized for what is considered lack of personal hygiene, bad odor, and habits that are considered primitive or even "savage" by the medical doctors, who are not indigenous, such as seating or eating in the floor. Finally, because the hospitals are hours (by car) or days away (by foot or public transportation) from their parajes, at the time the patient and its accompanying family members are released from the hospital they are faced with the difficulty of not having resources to go back to their communities (interviews and participant observation in the parajes, health posts, and hospitals of the Argentina side of the tri-border, August 2019).

Figure 1 about here

In Argentina, most of the responsibility for the delivery of health care to the population of tri-border area follows under the jurisdiction of the province of Salta, under its Ministry of Health. The national Ministry of Health oversees and evaluates programs. The area of the ADESAR/Mundo Sano intervention corresponds to two sanitary operational areas of the province (number 5, in the case of ALS and number 8 in the case of SVE) (see Map 3). There are two hospitals in these two sanitary operational areas. The Hospital of Alto La Sierra (ALS) provides basic care. It has a laboratory, but it does not have an ultrasound machine, for instance. Patients are derived from the Hospital of Alto La Sierra to the Hospital of Santa Victoria Este (SVE), for

\footnotetext{
${ }^{10}$ Pagina 12, "Salta: ambulancia se atascó en el barro y murió una beba en el translado al hospital," October 15, 2019, https://www.pagina12.com.ar/225323-salta-ambulancia-se-atasco-en-el-barro-y-murio-unabeba-en-e; last accessed 01/31/20
} 
slightly more complex care. Under favorable road conditions, it takes the ambulance almost two hours to drive from ALS to SVE, although it may take much longer during rainy season (from about December to April). The SVE hospital has a laboratory as well as an ultrasound machine. In fact, this machine was not in use prior to the ADESAR/Mundo Sano intervention. Together with the doctors and medical interns of the Hospital Italiano, the ADESAR/Mundo Sano doctors had the machine working again and trained a local doctor to use it and read ultrasounds. When patients need more complex care (such as intensive care, for instance), they are derived from the Hospital of SVE to the Tartagal Hospital (a 3-hour ambulance ride on paved road) or to a hospital in provincial capital of Salta (8-hours away in ambulance or shorter sanitary flight). ${ }^{11}$

Map 3 about here

In Bolivia, most of the responsibility for the delivery of health care to the population of triborder area follows under the Municipality of Yacuiba, under its Local Directory of Health (Directorio Local de Salud, DILOS). The Department of Tarija, under its Departmental Health Service (Servicio Departamental de Salud, SEDES) and the national Ministry of Health oversees and evaluates programs implemented at the municipal level. The area of the ADESAR/Mundo Sano intervention corresponds to the sanitary operational district number 5 . There are two health centers in this district, in Crevaux and D'Orbigny (PTDI YACUIBA 2016-2020). Both centers provide primary and secondary health services. In 2017, the Crevaux Health Center was in charge of 425 families, while the D’Orbigny Health Center took care of 387 families.

In Paraguay, the responsibility for the delivery of health care to the population of tri-border area follows under the department of Boquerón, which is the 16th health region of the country. The national Ministry of Health and Social Welfare oversees and evaluates programs implemented

\footnotetext{
${ }^{11}$ According to the hospital director, almost 14,000 inhabitants of the region depend on the Hospital of SVE care (interview with Marcela Quispe, August 2019).
} 
at the departmental and local level. In San Agustin, there is a Family Health Unit (Unidad de Salud de Familia), and, in Pozo Hondo, there is a basic health post. Both institutions provide basic primary care. In case of serious illnesses, patients are derived to regional hospital in Mariscal Estigarribia (220km away, and a four-hour ambulance ride on dirt roads).

\section{Medical Intervention}

The medical intervention consists of two-weeks of health care visits to six localities and their nearby villages or parajes, every other month. The intervention is part of the World Health Organization framework for the elimination of mother-to-child transmission of HIV, Syphilis, Hepatitis B, and Chagas (or EMTCT Plus). ${ }^{12}$ The first visit under the tri-border program took place in June of 2018 and is was programmed to run until mid-2021, albeit the program was suspended in March of 2020 to the Covid-19 pandemic. ${ }^{13}$ The tri-border program was built upon the expertise that the doctors of ADESAR had developed since 2016 in the locality of Alto La Sierra.

ADESAR, a non-profit NGO, was formed in 2009 by a team of Argentine doctors and biochemists (such as Favio Crudo, Mariana Fernández, Hugo Krupitzki, Sofia Murzicato, and Pablo Piorno, among others) who had been trained or worked closely in the public health sector with Dr. Orlindo Adrián Martino, an Argentine infectiologist and rural health doctor dedicated to tropical medicine. With experience in the administration of public health (mostly in localities of the Province of Buenos Aires) and with the goal of coordinating and aggregating their past experiences, the founders of ADESAR seek to contribute to the improvement of regional sanitary health and environments (particularly in rural and poor communities) through medical assistance,

\footnotetext{
${ }^{12}$ See program description at http://iris.paho.org/xmlui/handle/123456789/34306, last accessed 01/23/20.

13 The doctors of the health intervention flew from Buenos Aires to Salta. Hence, the program was suspended in March, when due to the pandemic all domestic flights were cancelled. The continue cancelled, and the intervention suspended, at the time of this writing.
} 
training of human resources, and primary research (interview with Sofia Murzicato, biochemist of ADESAR, SVE, August 7, 2019). According to ADESAR, their interventions are based on the principles of interdisciplinarity, scientific rigor, social sensitivity, and political independence. In developing their projects, they seek to coordinate with the local health authorities, to make sure that their projects are of interest to the community, viable, and scalable, and to develop alliances with other institutions and to promote community participation (see Figure 2).

Figure 2 about here

ADESAR arrived to ALS in September of 2016, as part of an intervention with mobile health care. They selected the area because it was one of the regions with the highest rates of infant and maternal mortality in Argentina. By mid 2018, ADESAR developed a program of maternal (including pre-natal and postpartum) and infant medical care for the tri-border area of the Great Chaco region and partnered with Mundo Sano for its financing and implementation.

Mundo Sano is a family foundation that seeks to contribute to public policies in health. It was created in 1993 by Roberto Gold, an Argentine pharmacist, and is primarily funded by the INSUD Pharma Group. Mundo Sano is primarily devoted to neglected tropical diseases. Mundo Sano's work on Chagas started at about the same time that ADESAR was being founded, in 2009, and in 2011 becomes part, with the pharma companies of the INSUD group, of a public-private consortium with the Ministry of Health of Argentina to produce benzinidazole to treat Chagas disease. ${ }^{14}$ INSUD stands for Innovation, Sustainability and Development, which are the core values of Mundo Sano founders, Silvia Gold and Hugo Sigman. Their projects are guided by designs that are meant to be scalable, sustainable, replicable, and transferable (see Figure 3). In the

\footnotetext{
${ }^{14}$ The INSUD group also agreed in August 2020 to mass-produce the Oxford Covid-19 vaccine while still on phase 3 of its trial, such that if successful the vaccine could be readily available to Latin American citizens.
} 
province of Salta, Mundo Sano has an office in the city of Tartagal, which provides a pickup truck and the medical and laboratory supplies required during the intervention.

Figure 3 about here

The Instituto Universitario del Hospital Italiano (a private university, part of a private hospital in the city of Buenos Aires) has a three-week long advanced students rotation in the locality of Santa Victoria Este. The medical students and interns also collaborate with the ADESAR/Mundo Sano intervention. For instance, in August 2019 they provided with a student ultrasound technician, a mobile ultrasound machine, and two medical students who were interns in pediatrics, and they accompanied the ADESAR/Mundo Sano team in the Hospital of SVE and in most of their visits to parajes on the Argentine side. The intervention also partners with the laboratory of the Hospital Alemán, another prestigious private hospital of Buenos Aires, were the non-rapid Chagas tests are performed. The laboratory of the Hospital Alemán also facilitates biochemistry interns who travel in some of the visits to the tri-border.

These ADESAR/Mundo Sano visits take place on the second and third weeks of the even months of the year and are organized in partnership with the provincial and local health authorities. These medical interventions started in June of 2018. The delivery consists primarily of prenatal checkups, ultrasounds, and rapid tests of HIV, Hepatitis B, Syphilis, and Chagas disease, which is endemic in the area. If a pregnant woman is diagnosed with Chagas, and she has children, then all the children are tested and if positive treated for Chagas. After a pregnant woman with Chagas gives birth she is also treated and her baby tested for Chagas. If the newborn's double test results are negative, another test is performed at 10 months of age.

When in location, together with the public medical staff, nurses, and/or sanitary agents, the ADESAR/Mundo Sano intervention consists of: 1) Health screening of the pregnant women: 
weight, blood pressure, and measurement of belly growth; 2) rapid lab test for HIV, Hepatitis B, Syphilis, and Chagas; and 3) ultrasound.

As these checkups and studies are done, the results are transcribed into the patient's medical record and in an ADESAR electronic database that is shared with the health authorities. In addition, local health officials may check the vaccination record of the pregnant women, provide iron supplements if the woman is anemic or underweight, and powder milk to help with her diet and nutrition needs during pregnancy.

From June of 2018 to October of 2019, this is to say over the course of nine visits to the area, the medical team provided prenatal and postpartum care to 878 women. Figure 4 shows the breakdown of pregnant women treated by country and ethnicity. For $31 \%$ of these patients, this was their first pregnancy. Figure 5 shows the number of prior pregnancies the rest of the patients had and Figure 6 shows their age at the time of the first pregnancy. When asked if their current pregnancy was planned, $23 \%$ of the patients said yes, whereas $72 \%$ responded no (the remainder 5\% did not respond), as illustrated in Figure 7.

Figures 4, 5, 6, and 7 here

\section{Coproduction in the ADESAR/Mundo Santo Intervention}

\subsection{The Data}

Our main goal is to evaluate the intervention from the point of view of coproduction. To such end, we used a multi-method approach. We carried out 26 in-depth interviews with state agents, plus two interviews with doctors from the NGOs and informal conversations with seven more NGO doctors and interns (see Table 2, for the country and type of agent breakdown). The interviews were carried out in Spanish, in August of 2019. Twenty-one of the interviews with 
public agents were recorded, and lasted from four minutes (an interview that had to be interrupted because the nurse had to leave the facility) to several hours (without considering the maximum and minimum length of interviews values, the average recorded minutes per interview was 20). The recorded interviews were later transcribed in Trint.com. The transcripts were revised for accuracy, and then uploaded and analyzed qualitatively for meaning and content. ${ }^{16}$ This paper focuses on the health care workers' opinions, which we analyzed according to the following dimensions: 1) access (and barriers) to health care, 2) diagnostic, treatment, and health outcomes, 3) human resources in health sector, and 4) financial/economic resources in health sector. We combine the information from the recorded interviews with the notes of the seven non-recorded interviews, our participant observation fieldnotes (taken by three of us during the two-week of intervention of August of 2019), and an unidentified database of pregnant women treatment and diagnostic results for those with prenatal visits form June 2018 to October of 2019.

Table 2 about here

We also conducted a survey of pregnant women who had prenatal checkups. While the sample is not random and probably not representative of all treated women, we sought to survey as many women as we could while they were waiting for their lab tests results (the rejection rate was about $10 \%$ ). In total, we surveyed just over half of the pregnant women who had prenatal checkups in the August 2019 intervention (103 surveyed women out of 193 who had prenatal check-ups). ${ }^{17}$

\subsection{Pregnant Women Access to Health Care}

\footnotetext{
${ }^{16} \mathrm{We}$ also plan to analyze the interviews using the Atlas.ti software.

${ }^{17}$ Because the survey was carried out in Spanish, and not in the women's native languages (as it should have ideally being the case), the reported survey results are for descriptive purposes only.
} 
Overall, we observed and were told that the ADESAR/Mundo Sano intervention increased pregnant women access to health care. This primarily happened through two mechanisms. First, it was reaching out patients in terrain, who would otherwise have gone untreated. The mobile health care aspect and the field visits to health posts in the parajes permitted to capture more pregnant women, whether they were seeing at home or brought from their homes to the clinic by the provincial ministry driver, or by the local nurse, or sanitary agent. For instance, during the second day of the August 2019 intervention, 16 pregnant women were picked up at their houses, brought to the health post of Santa Maria to have their prenatal checkups, and then driven back to their homes by the provincial ministry driver. ${ }^{18} \mathrm{~A}$ day earlier, in the locality of Monte Carmelo, the nurse tolds us: "Yo me encargo de buscarlas personalmente, una por una, y las hago atender a todas" [I personally go to pick each one of them up and make sure that they are all seen by the doctors]. And he went on to say "Hace 6 años que estoy aca y yo creo que las dos manos me sobran para decir las veces que han venido los médicos de Santa Victoria" [I have been here for six years and I can fit the times that the doctors of Santa Victoria have come here in the fingers of my hands] (Victor, nurse, Monte Carmelo). The field visits are an aspect of complementarity between state and NGOs intervention that was also recognized and praised by the directors of the two hospitals of the area. They recognized that they do not have the vehicles necessary to send doctors or nurses from the hospital to the communities, but that going with the ADESAR/Mundo Sano intervention (which implies at least two pickup trucks, one provided by the provincial ministry of health of Salta and the other by Mundo Sano) is ideal. The doctors of ADESAR/Mundo Sano intervention, on the other hand, make it a requirement that there should always be a state

\footnotetext{
${ }^{18}$ Pregnant women were driven from and to the communities of La Curvita (3), Padre Crol (4) El Tigre (4), and San Luis (5), on August 6, 2019.
} 
doctor or nurse accompanying them in the field visits. This, among other things, allows the state agents to track and follow patients and also to keep their medical records up to date. ${ }^{19}$

The second mechanism is walk-ins in health posts in the parajes, which are much closer to the pregnant women residences than the hospital of SVE or ALS, for instance. Thus, in the first day of the intervention, in the health post of La Puntana, the mother of one of the pregnant women who showed up for treatment said "Nos cuesta ir para Victoria" ["It is hard for us to make it to Santa Victoria"], and complained that their sanitary agent who is supposed to do home visits and provide powder milk to pregnant women, does not go by. Other women also brought their sick children, hoping the doctors of the intervention would check them-even if that day the doctors could only focus on the treatment of pregnant women. In that particular location, the doctors of ADESAR were expecting to see 17 pregnant women based on records from the June 2018 intervention, but eleven more pregnant women showed up. As the nurse of that health post said, when we asked her how many pregnant women were in La Puntana, "Nosotros teníamos 28 pacientes, pero ahora hay más. Hay más captadas, debe haber más de 40" ["We had 28 patients -in our records-, but now there are more. There are more we know about. There must be over 40.”] (Nurse, La Puntana)

As a result of these two mechanisms, and based on demographic estimations, the ADESAR/Mundo Sano doctors calculate the intervention captured close to $100 \%$ of the pregnant women of the region, with at least one prenatal checkup (See Table 3).

Table 3 about here

\footnotetext{
${ }^{19}$ In Salta, one copy of the pregnant women medical record or CLASP stays with the woman whereas the other paper copy stays in the local hospital and some information is uploaded to a centralized Ministry of Health database
} 
Moreover, in our own survey of pregnant women during the August 2019 intervention, 96\% said they had been treated well by the ADESAR/Mundo Sano, 90\% said they would recommend the ADESAR/Mundo Sano to a family member or friend, and 51\% said they would not have had a checkup at this time hadn't it been for the ADESAR/Mundo Sano intervention.

\subsection{Diagnostic and Treatment of Patients}

In terms of diagnostic and treatment of patients, the ADESAR/Mundo Sano intervention provides diagnostic technology and tools that are mostly not available in the hospitals and health clinics of the tri-border area. For instance, only the Hospitals in SVE and San Agustin have ultrasound machines - they are not existent in all the other health facilities of the area. With regards to blood tests, there are laboratories in SVE, ALS, Crevaux, and San Agustin, but none of those (or any other regional) facility conducts the rapid tests to diagnose Hep B, Syphilis, HIV, or Chagas. By providing mobile ultrasound machines, as well as a mobile lab with rapid tests for this mother-to-child-diseases, the medical intervention can provide diagnostic tools that are not available to the population of the area and that do affect their quality of care and decisions over treatment and hospital derivations. In this regard, the intervention complements the state health care system by providing technology and test that not readily available, neither in the parajes, nor in the population centers of the area. As the director of the Hospital of Santa Victoria Este-which is the one of higher level of complexity in the area-said:

“....al tener a ADESAR acá en Santa Victoria y controlar a todas las embarazadas, realizarle la ecografía y una serología es lo ideal. Para nosotros era muy complicado antes. Antes de que ellos estén acá lo que solíamos hacer es traer a las embarazadas en la ambulancia de las comunidades para sacarles la muestra de sangre y realizarle una 
ecografía, que lo hacíamos nosotros como médicos generalistas, que no era una ecografía así al 100\% buena, digamos. No. ... No le hacíamos ecografía porque el equipo era medio complicado llevarlo hasta el lugar." [To have ADESAR here in Santa Victoria, and to control all the pregnant women, to have the ultrasound, and the blood work is ideal. For us, it was very complicated before. Before they came, what we used to do was to bring the pregnant women from the communities here, in the ambulance to draw blood and do the ultrasound, which we — generalist doctors—did, so let's say it was not an ultrasound $100 \%$ good. No. ... In the communities we did not do ultrasound because it was difficult to take the ultrasound machine there.] (Marcela Quispe, Director Hospital Santa Victoria Este, August 2019).

Complementarity also plays a role in treatment. First, if the prenatal checkup or ultrasound reveal a complication, the woman is derived to the local hospital. Between June of 2018 and October of 2019, 30 women were derived to a hospital due to health risks (see Table 4). Second, when a pregnant woman or their children are diagnosed with one of these four diseases that are transmitted from mother to child, it is up to the state health system to provide the medicine for treatment and to follow up compliance with treatment. And whereas the doctors of the intervention do follow up with Chagas positive patients in their subsequent visits so observe compliance with treatment, the primary responsibility for monitoring treatment in these patients follows with the local sanitary agents. Table 5 shows the number of pregnant women who were diagnosed with Chagas and Syphilis in each country (there were no cases of HepB or HIV) and Table 6 shows the number or patients (mothers and children) treated for Chagas from June 2018 to October 2019.

Tables 4,5 , and 6 here 


\subsection{Human Resources in the Health Care Sector}

Deserrano et al (2019) found that in the medical NGO intervention they studied, the NGOs competed for human and financial resources with the state, crowding it out. This is not the case in the ADESAR/Mundo Sano intervention, mostly because it has a different institutional design. On the contrary, in the three countries of the tri-border public health agents praised the possibility of having access to specialists such as obstetricians, gynecologists, or pediatricians, as the doctors who are in the area are almost exclusively generalist or family doctors. One of the nurses, for instance said:

"Porque acá no tenemos médico. Años y años que nosotros estamos trabajando solos, sin médicos. Y las veces que si una persona, tanto como una embarazada, un adulto o un niño, si tiene problemas, nosotros no sabemos porque falta el informe de los médicos. Lo que más sufrimos es el tema de vehículo, del transporte de los pacientes, los medicamentos y la visita médico, que años que no tenemos médico acá. Yo trabajo sola, como auxiliar de enfermería. No soy profesional. Y las veces que se te muere un chico, una embarazada, una puérperas... y es un lamento para nosotros, digamos. Y las veces que me pongo a llorar sola en el puesto." [Here we don't have a doctor. It has been years that we are working alone, without doctors. If a person, a pregnant woman, an adult or a child has a problema, we don't know it becuase the medical record is missing. What we suffer the most it the lack of vehicle, to transport patients, of medicines, and of doctors' visits. Because we haven't had a doctor here for years. I work alone, as a nurse assistant. I am not a professional. There are times when a kid dies, or a pregnant woman, or a new mom, and it is a cry for us, let's say. [And I can't tell you] the times that I just cry, alone, here in the health post.] (Maria, nurse La Puntana, Argentina). 
Thus, in terms of human resources, the ADESAR/Mundo Sano intervention provides complementarity in skills and training. Doctors of the intervention occasionally give workshops to local health officials. Meanwhile, the state agents provide the intervention with access to information on women who are pregnant, as well as knowledge on geographical access to remote locations or dwellings of families who relocate throughout the seasons. As at mentioned above, while the ADESAR/Mundo Sano doctors provide diagnosis and derivations to hospitals for emergency care, public health agents are in charge of treatment and monitoring.

In terms of embeddedness, the intervention employs one Wichi interpreter in ALS and as necessary may also employ an extra driver and rent a pickup truck from a local community member. They also rely on the local communities for housing (including at the local church in SVE) and food. The government of Salta, on the other hand, employs and works with members of the local communities, both creoles and indigenous, as sanitary agents. There are 47 sanitary agents in total in the two sanitary operational areas on the Argentine side (for a rural and dispersed population of over 15,000 people). They live and work in their communities and are responsible for regular household visits to conduct primary health care (such as vaccinations, blood pressure controls, and measurements) and provide iron, vitamin supplements, or powdered milk to pregnant women - when available. Sanitary agents are assigned a territorial area and a motorcycle as transportation. Both pregnant women as well as local doctors and public health officials complained that in some cases sanitary agents' work was unreliable and communities went with unmet health needs. They also complained that indigenous sanitary agents are hard to retire or fire, due to threat of protests. As a public health official put it:

“Con los agentes sanitarios ... se trabaja coordinadamente con ellos, porque ellos son los primeros o son los que están en contacto día a día con las familias de los diferentes 
sectores. Últimamente estamos teniendo medio problemas de que ellos no están yendo a visitar como corresponde. No están yendo a aplicar la vacuna o a hacer el trabajo que deben realizar ... Ellos tienen que ser responsables, hacerse cargo del sector que se les designó. Pero no todos tenemos la misma idea de que tengo que trabajar, tengo que hacer esto, levantarme temprano y decir, '-ay! no lo vacune a ese niño,- ese niño nació ayer, le falta la vacuna, - tengo una paciente embarazada que tiene 12 años.' No sé si no tienen esa alarma, o no les importa. ... Lo que tenemos problema son con los agentes sanitarios originarios. Ellos son los que tienen problemas, todos.... no trabajan como tendrian que trabajar. Tenemos un cacique que es político. En vez de atender se va a hacer política. Entonces se nos complica. Vos lo querés cambiar, lo querés echar, te cortan la ruta, ... , entendés?" [With the sanitary agents ... we work in coordination, because they are the first ones, or the ones who have day-to-day contact with the families of their sectors. Lately, we are having some problems with some who are not doing house visits as they should. They are not going to vaccinate or do the job they ought to do ... They must be responsible, be in charge of the sector assigned to them. But not all of us have the idea that we must work, wake up early and say '-hey, I need to vaccinate this kid' or 'that kids was born yesterday and is missing a vaccine' or '-I have a pregnant patient who is 12 years-old,' I don't know whether they don't have that sense of alarm or they just don't care ... The [biggest] problem is with the indigenous sanitary agents. They are the ones who have problems, all of them ... they don't work as they are supposed to. We have a cacique who is a politician. Instead of seeing patients he leaves to do politics. So it gets complicated for us. If you want to change that person, if you want to fire him, they organize a barricade in the highway, you see?] (public health official, Argentina, August 2019) 
This is say, whereas the state seeks to train and employ people in the communities as sanitary agents, most of those who are indigenous are perceived as lazy and not doing their work. Triangulating with the opinions of women from some indigenous communities, it appears that the reality is mixed: some indigenous sanitary agents are doing their work, others are not, and the same could probably be said of those who are non-indigenous. Indigenous communities, on their part, mostly perceive the state as foreign and extractive, and historically exploitative. They also feel discriminated within the public health care system.

\subsection{Financial resources in the health care sector}

Financed mostly by Mundo Sano, it appears that the intervention complements the resources of the public health care sector in the localities of the tri-border area. Doctors of the intervention receive "an opportunity cost fee", which amounts to approximately USD200 per week, plus transportation costs to fly from Buenos Aires to Salta, and room and board while in the tri-border area. An early estimate sets the cost of each prenatal checkup (including ultrasounds and lab tests) at USD40.

\subsection{Complementarity... and embeddedness?}

Figure 8 illustrates the flow of the main relationships among state agents, NGOs, and individual patients and communities in the ADESAR/Mundo Sano intervention, as so far described. The thickness of the arrows aims to represent the relative strength of that relationship when compared to others.

Figure 8 about here 
In terms of the triangular relationship of coproduction between state, NGOs, and patients, the tri-border medical intervention shows that there is a strong benefit to states and patients in the intervention of the NGOs. The NGO doctors provide training to public health care workers, make available resources that the states do not have (such as portable ultrasound machines, portable labs, quick tests, and transportation). For patients, the NGOs presence in the region augments the access to prenatal visits and tests and treatment on mother-to-child transferred diseases. The states, on the other hand, provided fewer resources to the intervention. The NGOs doctors required that at least one public health worker accompanied them when doing home visits. But the most important asset provided by the Salta government was an experienced, well-liked, and trusted driver. This driver facilitated communication between the NGO doctors and the patients, particularly those in isolated parajes. This driver had a granular knowledge of the area and its inhabitants and was trusted and respected. The three states also facilitated access to patients' information and collaborated such that the NGO intervention could create a patients' electronic database to follow up pregnancies and treatments in between and during visits. This database was shared with the public health workers. The states relationships to patients were as expected (i.e., provision of health care services, economic subsidies, etc.) Perhaps more interesting there was a tenuous relationship between patients, or more precisely their communities, and the provincial government of Salta. This government recruited members of the indigenous communities to be publicly employed "sanitary agents" in charge of a territorially designated area. In such areas, these agents (usually with a basic level of education and trained in basic health care provision) would provide vaccinations and serve as liaisons between the indigenous communities and the doctors or nurses of the health care centers. 
Possibly the weakest of all relationships in this triangular coproduction scheme was that one between patients and the NGO. Only one interpreter who was an indigenous community member worked closely with the intervention doctors in the Alto La Sierra hospital.

This is to say, in this intervention patients' participation in coproduction of their health care was extremely low (or non-existent). The barriers to increasing such participation appear unsurmountable, as there are barriers of language, culture, low levels of trust, and a history of institutionalized racism and structural dispossession and exclusion. Nonetheless, it is in patients' higher levels of involvement and participation in the intervention where the key resides to the success of treatments such as Chagas (which requires prolonged intake of daily medicine that has adverse secondary effects). The participation and involvement of these communities is also important for this intervention to be eventually transferable to the local health authorities (which as an aspiration of the NGOs). Yet, indigenous women participation seems impossible without an intercultural approach to health, which the intervention does not have. This is evidence of the lack

of embeddedness of the intervention in the local communities. Western medicine is practiced with the best intentions by this group of caring doctors, but without an appreciation for indigenous traditional health practices or cultural protocols it is unclear whether the intervention will have long lasting effects.

\section{Conclusion}

In analyzing the ADESAR/Mundo Sano intervention in the tri-border area among Argentina, Bolivia, and Paraguay, in the Great Chaco region, the concept of coproduction is valuable. There is no doubt that there is complementarity in the capacities of the public health system and the capacities of the mobile health care type of intervention that the doctors of 
ADESAR/Mundo Sano can provide. Whereas the few state health resources and doctors are concentrated in the small urban centers of the area, the intervention means the possibility of taking public health officials to the field, to the parajes that are insufficiently covered and practically not reached by the public health care system. The fact that the intervention returns every two months helps health care agents in the parajes (nurses and sanitary agents) to plan and look forward to those checkups. There is also complementarity between state and NGOs intervention in that the state provides at least one driver and pickup to mobilize part of the intervention doctors, and local information on residents and their location. There is also complementarity in that the intervention is implemented with state agents' side by side NGO doctors, which facilitates training and book keeping in the patients' medical records. There could also be complementarity in financial resources (albeit at this time we lack sufficient information on this dimension). Finally, the intervention has interesting spillover effects, such as registration of children who might not have been officially registered and access to contraception for women (especially those under 20 years of age) who request it.

However, the intervention seems to have a very shallow level of embeddedness. It is in this regard that the most improvements could be made. The intervention treats a majority of indigenous women, and within these there are more than five ethnicities. Communication in Spanish is certainly possible and somehow fluid with some ethnicities, but not with the Wichi or Wennhayek women. In our opinion, Wichi and Wennhayek women should have prenatal checkups in the presence of a female indigenous interpreter, preferably from their own communities. Furthermore, doctors (both from the state and the NGOs) and patients would greatly benefit from an intercultural approach to health care. Of course, these are high demands for an area that is currently under sanitary emergency, where hanger, malnutrition, and dehydration--due to lack of potable or clean 
water--are paramount, and land tenure is insecure. Furthermore, the covid-19 pandemic is layered on top of these problems and has implied the suspension of the medical intervention. The study of this intervention shows, nonetheless, that much can be gained from private-public collaborations such as the ADESAR/Mundo Sano medical intervention, which in terms of complementarities is above and beyond the sporadic interventions of other NGOs in the area of SVE. Yet, greater embeddedness, at least between the intervention and the local indigenous communities, could significantly improve the care provided to pregnant women and families in the area. The employment of language and cultural interpreters, and the training of doctors on traditional medicine and health care practices of the communities are two ways of improving this coproduction.

More generally, the health care coproduction in the Chaco tri-border area highlights the importance of embeddedness in coproduction experiments, a dimension that Elinor Ostrom largely overlooked. Coproduction is not simply a matter of costs and benefits in a production function, given certain public budget constraints. Complementarity and collaboration between states and NGOs is important and it goes a long way in terms of expanding access to health care services. However, for a coproduction to be fully successful and possibly transferable to local communities once the intermediary NGOs are removed, patients' participation is essential. The obstacles to such participation in indigenous territories are many. Nonetheless, tapping on indigenous communities' local and ancestral knowledge and traditions is one way to start increasing embeddedness in coproduction where this dimension is absent or lacking. 


\section{References}

Amengual, Mathew. 2016. Politicized enforcement in Argentina: labor and environmental regulation. New York: Cambridge University Press.

Amengual, Mathew, and Eduardo Dargent. 2020. "Teh Social Determinants of Enforcement: Integrating Politics with Limited State Capacity." In Teh Politics of Institutional Weakness in Latin America, ed. D. M. Brinks, S. Levitsky and M. V. Murillo. New York: Cambridge University Press, 161-82.

Austen, Soibhan, and Therese Jefferson. 2019. "Crossing the Great Divide: Ostrom's Coproduction and the Economics of Aged Care." Feminist Economics 25 (3), 48-69.

Batalden, Maren, Paul Batalden, Peter Margolis, Michael Seid, Gail Armstrong, Lisa OpipariArrigan, and Hans Hartung. 2016. "Coproduction of healthcare service." BMJ Qual Saf25, 509-17.

Deserrano, Erika, Aisha Nansamba, and Nancy Qian. 2019. "Aid Crow-Out: Teh Effect of NGOs on Government-Provided Public Srevices." ed. N. K. M. a. N. Uganda.

Evans, Peter. 1995. Embedded Autonomy: States and Industrial Transformation. Princeton, NJ: Princeton University Press.

1996a. "Government Action, Social Capital and Development: Reviewing the Evidence on Synergy." World Development 24 (6), 1119-32.

_. 1996b. "Introduction: Development Strategies across the Public-Private Divide." World Development 24 (6), 1033-7.

Falleti, Tulia G., and Santiago L. Cunial. 2018. Participation in Social Policy. Public Health in Comparative Perspective. New York: Cambridge University Press.

Goodwin, Geoff. 2019. "The problem and promise of coproduction: Politics, history, and autonomy." World Development 122, 501-13.

Kremer, Michael, and David Clingingsmith. 2007. "Case Study. Delivering Health Care."

Offner, Amy C. 2019. Sorting out the Mixed Economy.The Rise and Fall of Welfare and Developmental States in the Americas. Princeton, NJ: Princeton University Press.

Ostrom, Elinor. 1996. "Crossing the Great Divide: Coproduction, Synergy, and Development." World Development 24 (6), 1073-87. 


\section{Map 1. The Great Chaco region}

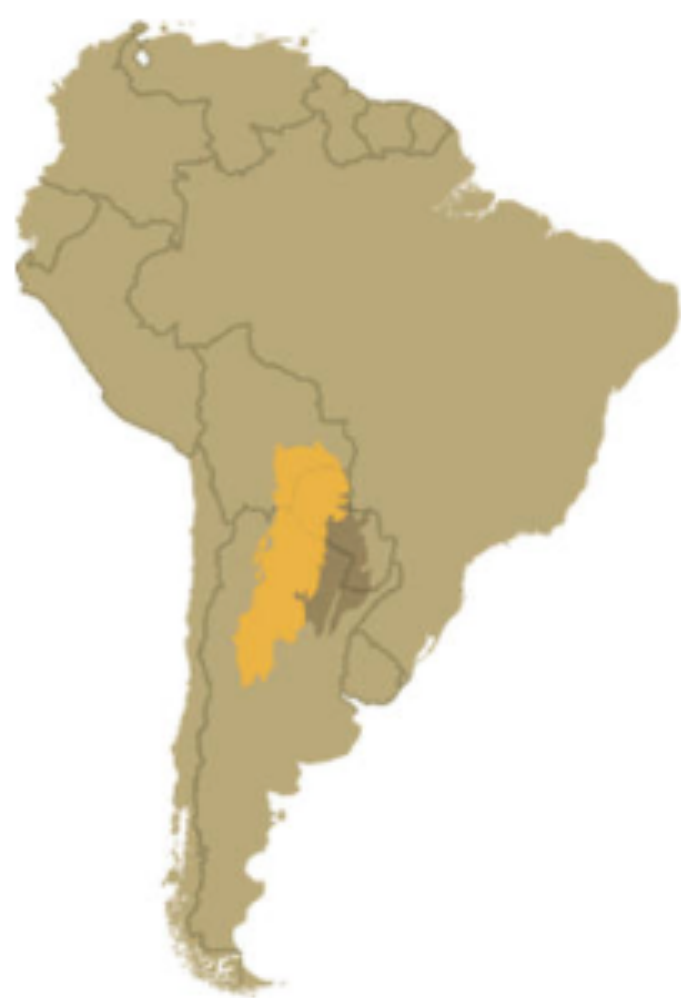

Source: Word Wildlife Foundation, accessible at https:/www.worldwildlife.org/magazine/issues/summer-2018/articles/exploring-the-gran-chaco, consulted on $1 / 22 / 2020$. 
Table 1 - Socioeconomic and demographic data (department or municipal level), Tri-Border Area, Great Chaco

\begin{tabular}{|c|c|c|c|c|c|}
\hline \begin{tabular}{|c|} 
Municipalit \\
y/Departme \\
nt
\end{tabular} & $\begin{array}{c}\text { Total Population } \\
\text { (YEAR) }\end{array}$ & $\begin{array}{c}\text { Indigenous } \\
\text { Population (\%) } \\
\text { (YEAR) } \\
\end{array}$ & $\begin{array}{c}\text { Infant Mortality under } 1 \\
\text { year of age, per } 1,000 \\
\text { (YEAR) } \\
\end{array}$ & $\begin{array}{c}\text { Infant Mortality under } 5 \\
\text { years of age, per } 1,000 \\
\text { (Year) } \\
\end{array}$ & $\begin{array}{c}\text { Maternal Mortality, per } \\
100,000 \text { (Year) }\end{array}$ \\
\hline $\begin{array}{l}\text { Rivadavia } \\
\text { Department } \\
\text { (ARG) }\end{array}$ & $\mathbf{3 3 , 0 8 8}$ (2015) (a) & $\mathbf{3 3 . 8 3 \%}$ (2010) (b) & $8.98(2015)(c)$ & $7.19(2015)(c)$ & 35.9 (2015) (c) \\
\hline $\begin{array}{c}\text { Yacuiba } \\
\text { Municipality } \\
\text { (BOL) }\end{array}$ & $\mathbf{8 9 , 9 8 3}(2012)(\mathrm{d})$ & $\mathbf{5 3 . 3 \%}(2012)(\mathrm{d})$ & 18.8 (2016) (e) & 23.2 (2016) (e) & $\begin{array}{l}\mathbf{6 3} \text { (2011, data corresponds } \\
\text { to TARIJA department) (f) }\end{array}$ \\
\hline \begin{tabular}{|c|} 
Boqueron \\
Department \\
(PAR)
\end{tabular} & $\mathbf{6 1 , 1 0 7}(2012)(\mathrm{g})$ & $\mathbf{4 4 . 9 \%}(2012)(\mathrm{h})$ & $18.2(2010)(\mathrm{i})$ & 27.6 (2010) (i) & 79 (2010) (i) \\
\hline
\end{tabular}

Notes and Sources:

(a) Ministerio de Salud, 2016, Natalidad, mortalidad general, infantil y materna por lugar de residencia Argentina - Año 2015 , Buenos Aires: Ministerio de Salud de la Nacion (http://www.deis.msal.gov.ar/wp-content/uploads/2016/12/BoletinNro154xlugardeResidencia.pdf)

(b) Our own calculation based on the extended questionaire, 2010 Argentine National Census (https://www.indec.gob.ar/indec/web/Nivel4-Tema-2-41-135)

(c) Our own calculation based on data from (a)

(d) 2012 Bolivia Census. Base Redatam.

(e) UDAPE, 2018, La Mortalidad Infantil y en la Niñez en Bolivia: Estimaciones por Departamento y Municipio . La Paz: Unidad de Análisis de Políticas Sociales y Económicas. (http://www.udape.gob.bo/portales_html/docsociales/mortalidad-infantil-ninez-Bolivia.pdf)

(f) Gobierno Autonomo Municial de Yacuiba, 2018, Plan Territorial de Desarrollo Integral PTDI 2016-2020.

(http://www.gamy.gob.bo/poa/PTDI\%20YACUIBA\%202016-2020.pdf)

(g) DGEEC, 2013, Anuario Estadístico del Paraguay 2012, Asuncion: Dirección General de Estadística, Encuestas y Censos. (https://www.dgeec.gov.py/Publicaciones/Biblioteca/anuario2012/anuario\%202012.pdf)

(h) Our own calculation based on data from DGEEC, 2016, Atlas Demografico del Paraguay, 2012. Fernando del Mora: Dirección General de Estadística, Encuestas y Censos. (https://www.dgeec.gov.py/Publicaciones/Biblioteca/atlas-demografico/Atlas\%20Demografico\%20del\%20Paraguay,\%202012.pdf)

(i) DIGIES, 2012, Indicadores Básicos de Salud 2012. Asunción: Dirección General de Información Estratégica en Salud, Ministerio de Salud Pública y Bienestar Social. (https://iris.paho.org/bitstream/handle/10665.2/31383/index.pdf?sequence=1\&isAllowed=y) 
Map 2. Hand-drawn map of the parajes visited by the ADESAR/Mundo Sano team on the Argentine side of the tri-border area of the Great Chaco.

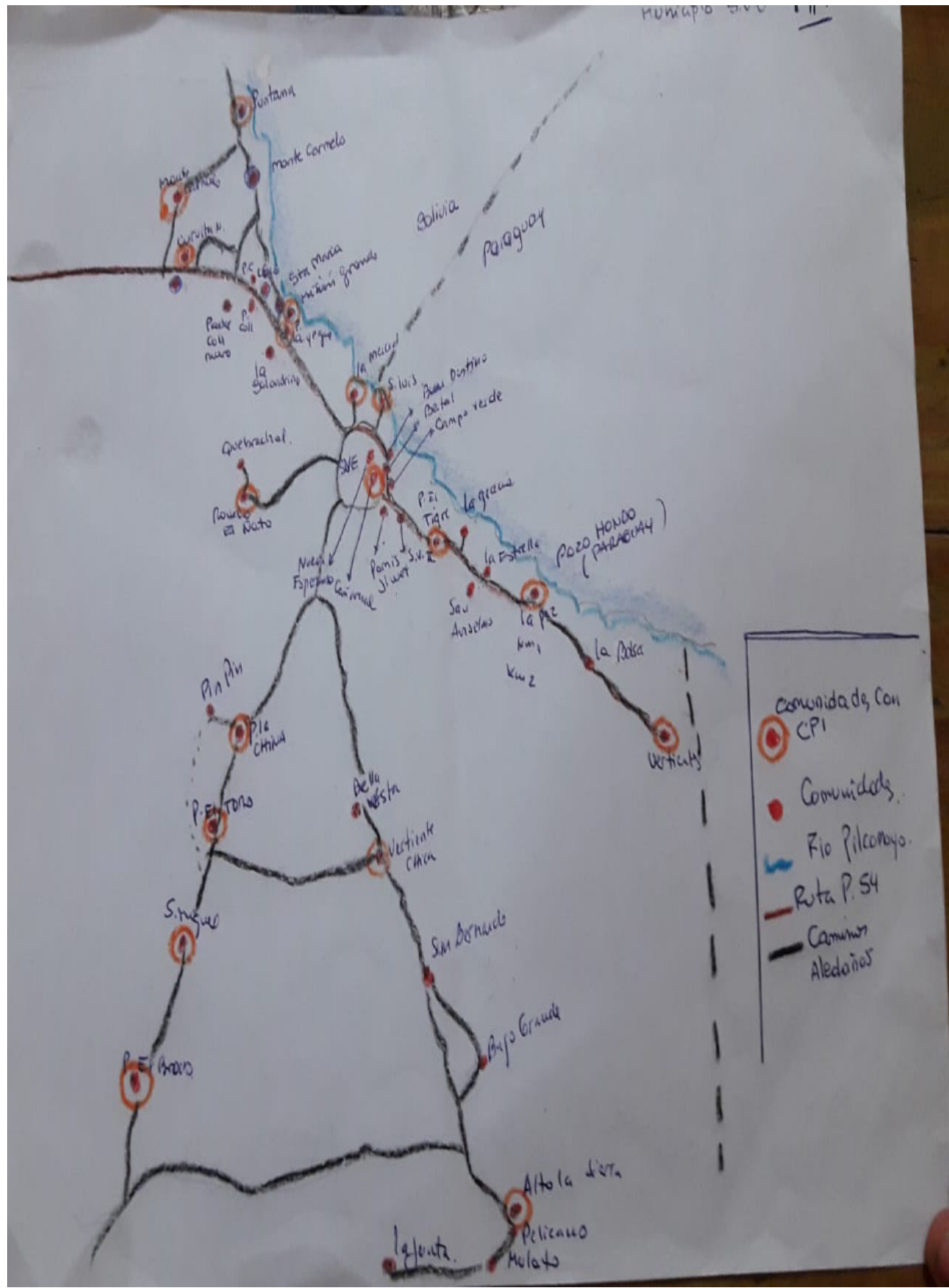

References (in the order they are listed vertically): Communities with Centers of Early Childhood; communities; Pilcomayo River; Provincial Highway 54; Side [dirt] Roads. 
Figure 1. Photo of wichí family dwelling, paraje near Alto La Sierra, Salta, Argentina.

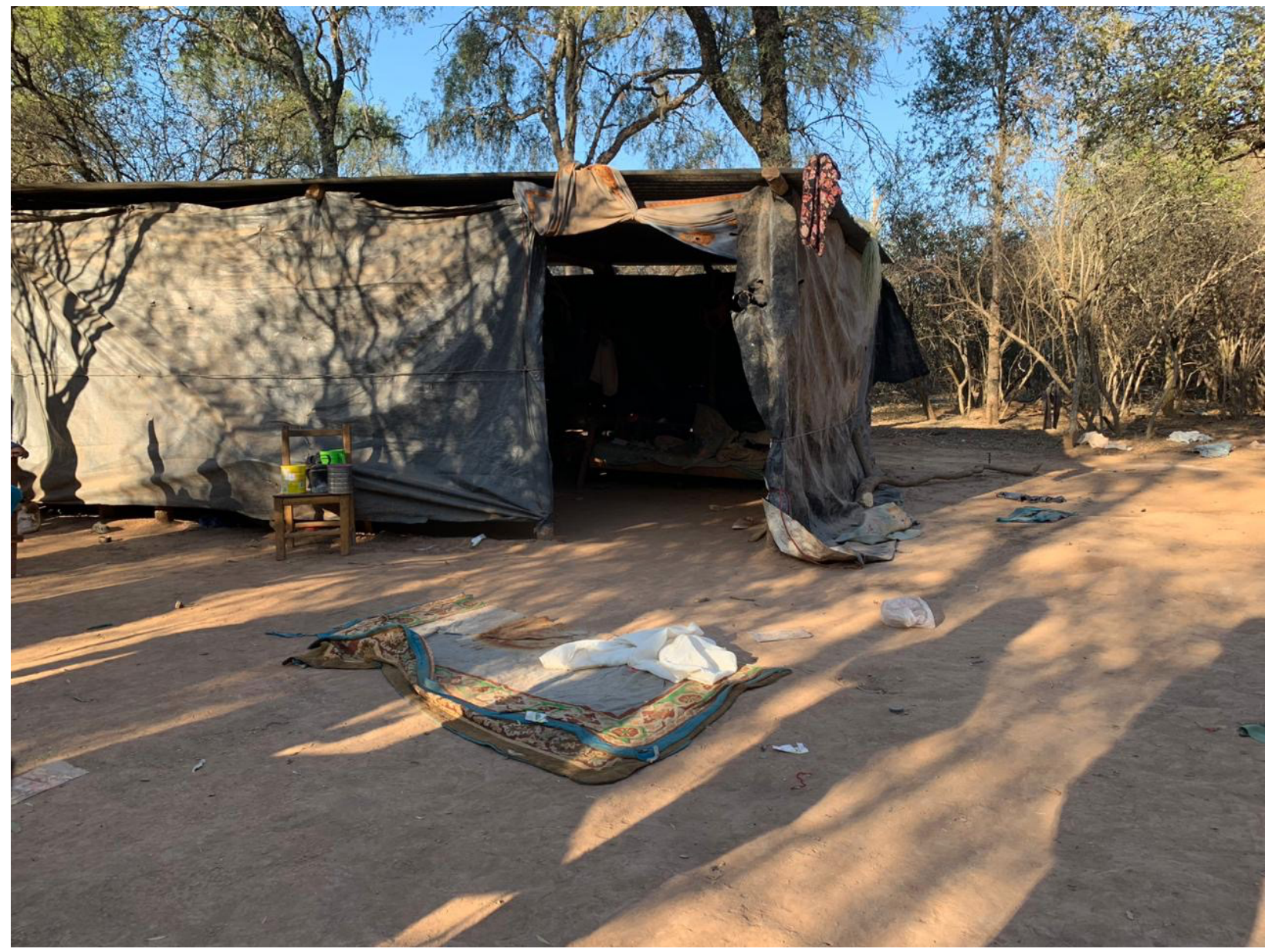

Photo by Mauro Escalante, August 13, 2019 


\section{Map 3. Location of hospitals and sanitary operational areas in the Salta province}

HOSPITALES DEL INTERIOR DE LA PROVINCIA DE SALTA

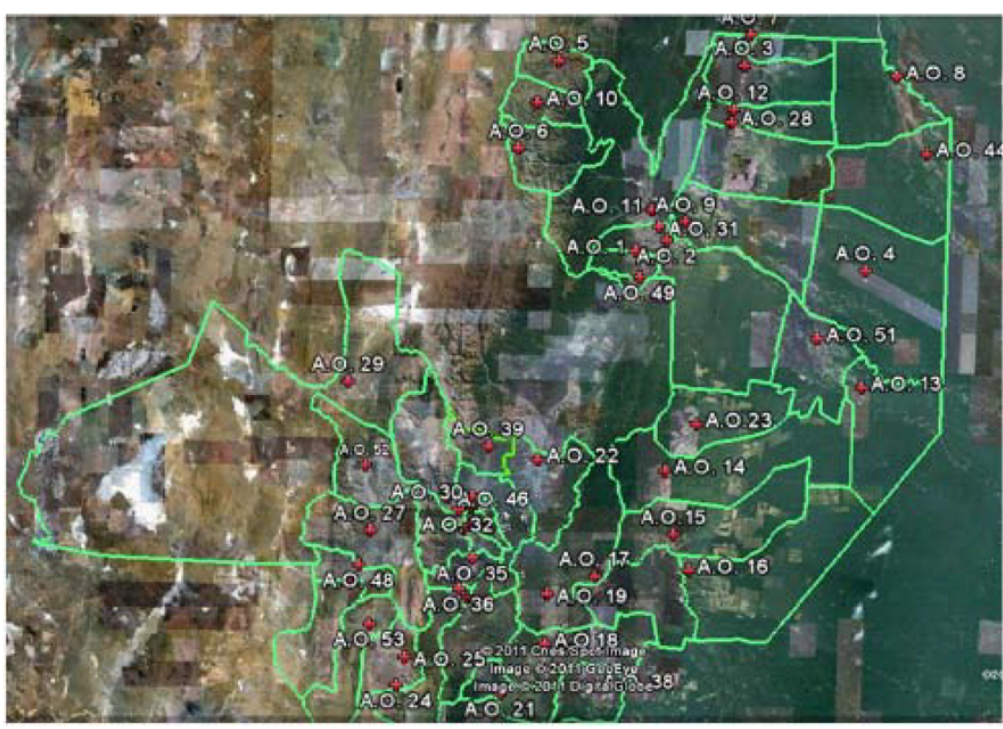

\begin{tabular}{|l|l|l|}
\hline Área Op. 1 - Colonia Santa Rosa & Latitud & $23^{\circ} 23^{\prime} 42.99^{\prime \prime} \mathrm{S}$ \\
\cline { 2 - 3 } & Longitud & $64^{\circ} 25^{\prime} 46.06^{\prime \prime} \mathrm{O}$ \\
\hline
\end{tabular}

\begin{tabular}{|l|l|l|}
\hline Área Op. 2 - Pichanal & Latitud & $23^{\circ} 19^{\prime} 33.02^{\prime \prime} \mathrm{S}$ \\
\cline { 2 - 3 } & Longitud & $64^{\circ} 13^{\prime} 18.12^{\prime \prime} \mathrm{O}$ \\
\hline
\end{tabular}

\begin{tabular}{|l|l|l|}
\hline \multirow{2}{*}{ Área Op. 3 - Aguaray } & Latitud & $22^{\circ} 14^{\prime} 39.23^{\prime \prime} \mathrm{S}$ \\
\cline { 2 - 3 } & Longitud & $63^{\circ} 44^{\prime} 10.87^{\prime \prime} \mathrm{O}$ \\
\hline
\end{tabular}

\begin{tabular}{|l|l|l|}
\hline \multirow{2}{*}{ Área Op. 4 - Morillo } & Latitud & $23^{\circ} 28^{\prime} 17.57^{\prime \prime} \mathrm{S}$ \\
\cline { 2 - 3 } & Longitud & $62^{\circ} 53^{\prime} 19.39^{\prime \prime} \mathrm{O}$ \\
\hline
\end{tabular}

Área Op. 5 - Santa Victoria Oeste

\begin{tabular}{|l|l|}
\hline Latitud & $22^{\circ} 15^{\prime} 6.20^{\prime \prime} \mathrm{S}$ \\
\hline Longitud & $64^{\circ} 57^{\prime} 52.01^{\prime \prime} \mathrm{O}$ \\
\hline
\end{tabular}

\begin{tabular}{|l|l|}
\hline \multicolumn{2}{|l|}{ Área Op. 6 - Iruya } \\
\hline Latitud & $22^{\circ} 47^{\prime} 31.30^{\prime \prime} \mathrm{S}$ \\
\hline Longitud & $65^{\circ} 13^{\prime} 0.49^{\prime \prime} \mathrm{O}$ \\
\hline
\end{tabular}

\begin{tabular}{|l|l|}
\hline \multicolumn{2}{|l|}{ Área Op. 7 - Salvador Maza } \\
\hline Latitud & $22^{\circ} 3^{\prime} 15.12^{\prime \prime} \mathrm{S}$ \\
\hline Longitud & $63^{\circ} 41^{\prime} 45.42^{\prime \prime} \mathrm{O}$ \\
\hline
\end{tabular}

\begin{tabular}{|l|l|}
\hline \multicolumn{2}{|l|}{ Área Op. 8 - Santa Victoria Este } \\
\hline Latitud & $22^{\circ} 16^{\prime} 19.55^{\prime \prime} \mathrm{S}$ \\
\hline Longitud & $62^{\circ} 42^{\prime} 53.21^{\prime \prime} \mathrm{O}$ \\
\hline
\end{tabular}

\begin{tabular}{|l|l|}
\hline \multicolumn{2}{|l|}{ Área Op. 9 - Embarcación } \\
\hline Latitud & $23^{\circ} 12^{\prime} 41.58^{\prime \prime} \mathrm{S}$ \\
\hline Longitud & $64^{\circ} 5^{\prime} 59.99^{\prime \prime} \mathrm{O}$ \\
\hline
\end{tabular}

\begin{tabular}{|l|l|}
\hline \multicolumn{2}{|l|}{ Área Op. 10 - Nazareno } \\
\hline Latitud & $22^{\circ} 30^{\prime} 31.85^{\prime \prime} \mathrm{S}$ \\
\hline Longitud & $65^{\circ} 6^{\prime} 5.31^{\prime \prime} \mathrm{O}$ \\
\hline
\end{tabular}

\begin{tabular}{|l|l|}
\hline \multicolumn{2}{|l|}{ Área Op. 11 - Orán } \\
\hline Latitud & $23^{\circ} 8^{\prime} 35.31^{\prime \prime} \mathrm{S}$ \\
\hline Longitud & $64^{\circ} 19^{\prime} 28.39^{\prime \prime} \mathrm{O}$ \\
\hline
\end{tabular}

\begin{tabular}{|l|l|}
\hline \multicolumn{2}{|l|}{ Área Op. 12 - Tartagal } \\
\hline Latitud & $22^{\circ} 31^{\prime} 1.37^{\prime \prime} \mathrm{S}$ \\
\hline Longitud & $63^{\circ} 47^{\prime} 52.85^{\prime \prime} \mathrm{O}$ \\
\hline
\end{tabular}

\begin{tabular}{|l|l|}
\hline Área Op. 13 - Rivadavia Banda Sur \\
\hline Latitud & $24^{\circ} 11^{\prime} 2.53^{\prime \prime} \mathrm{S}$ \\
\hline Longitud & $62^{\circ} 53^{\prime} 16.42^{\prime \prime} \mathrm{O}$ \\
\hline
\end{tabular}

Source: Salta, Plan quinquenal 2011-2016 


\section{Figure 2. ADESAR Philosophy and Approach to Sanitary Programs}

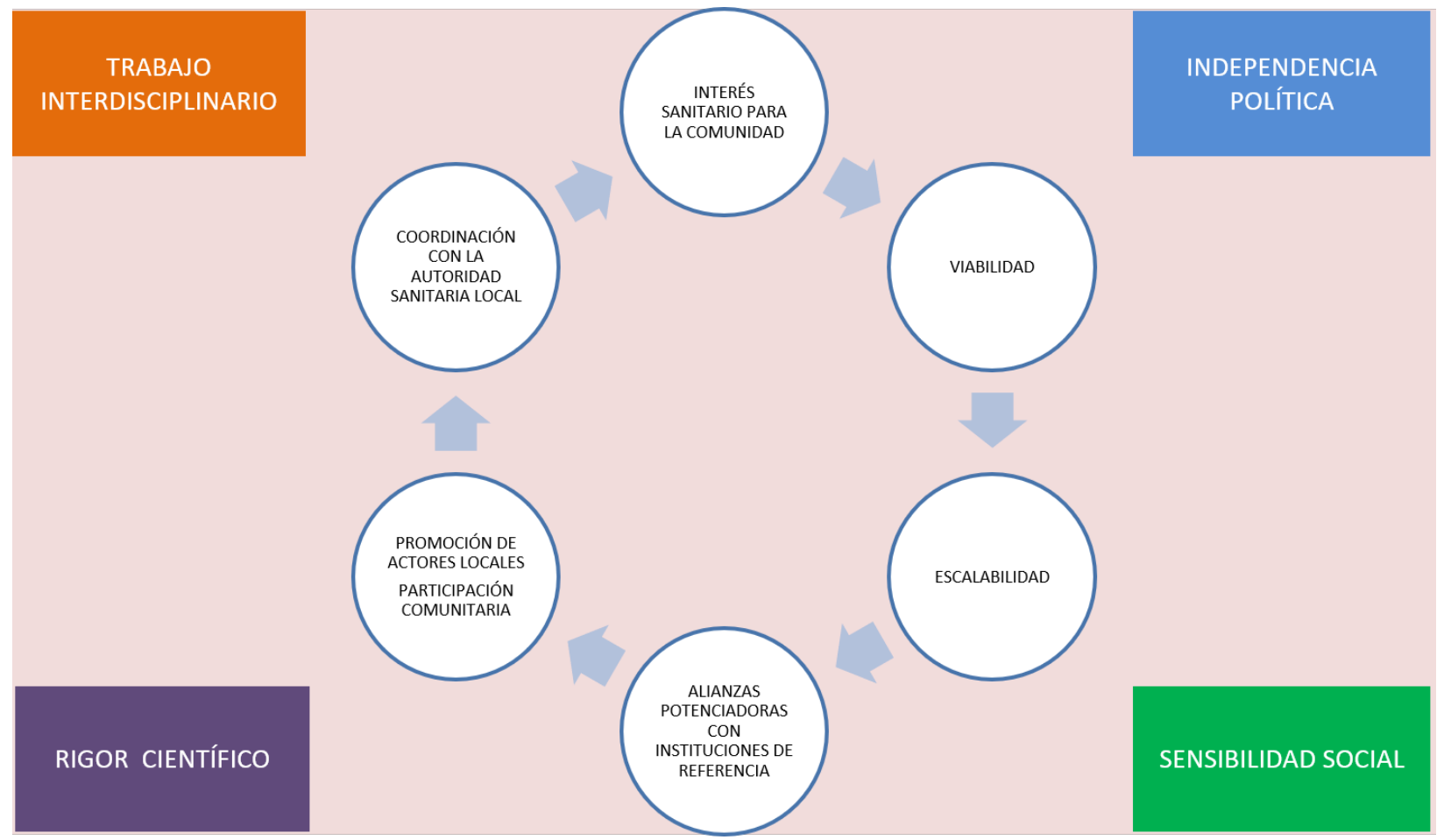

Source: http://adesar.org.ar/wp-content/uploads/2019/06/como-lo-hacemos.png, last accessed $01 / 23 / 2020$ 
Figure 3. Philosophy and Approach to Their Projects

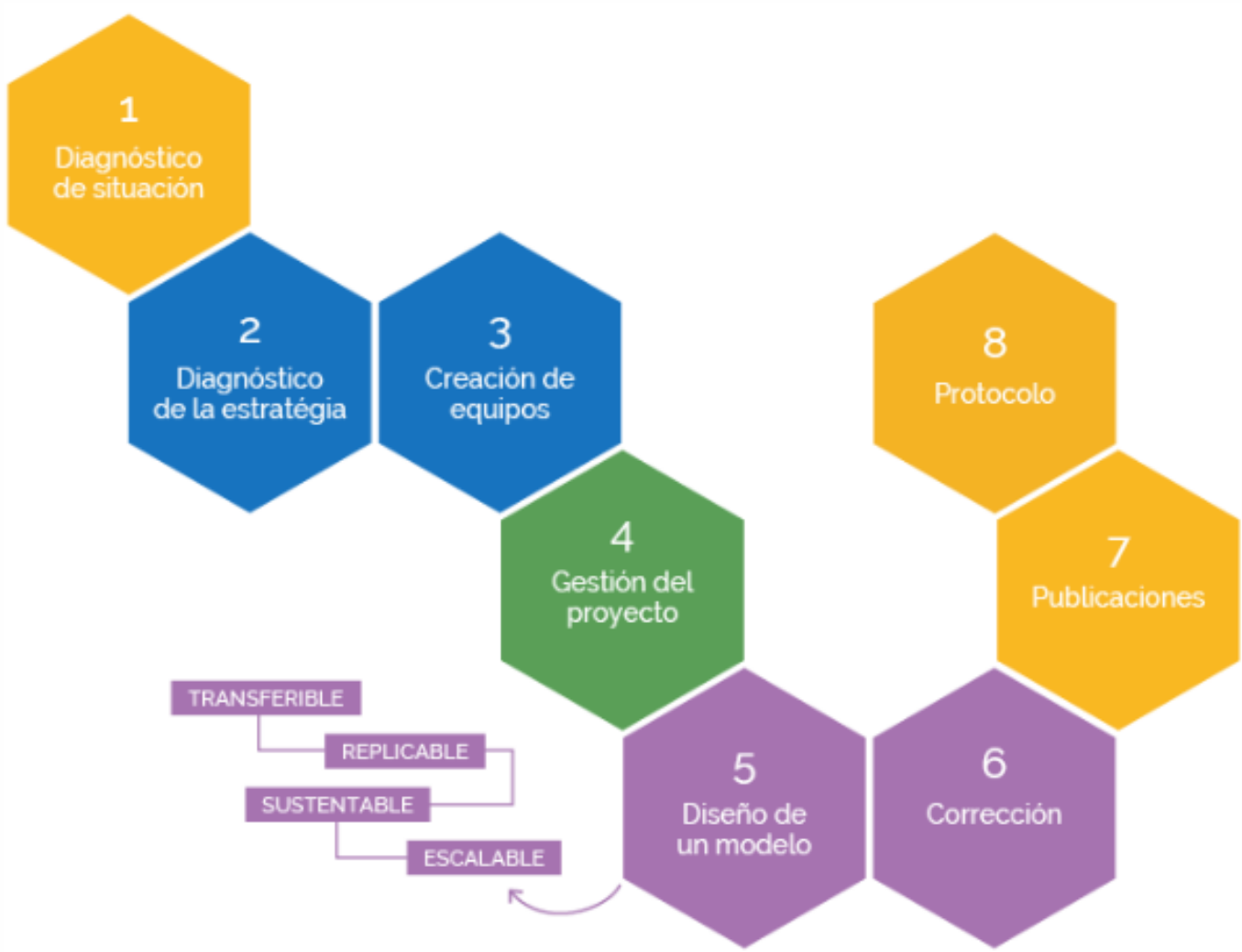

Source: https://www.mundosano.org/en/about-us/, last accessed 01/23/2020 
Figure 4. Pregnant Women Checked-up by ADESAR/Mundo Sano intervention, by country and ethnicity, June 2018 to October 2019.

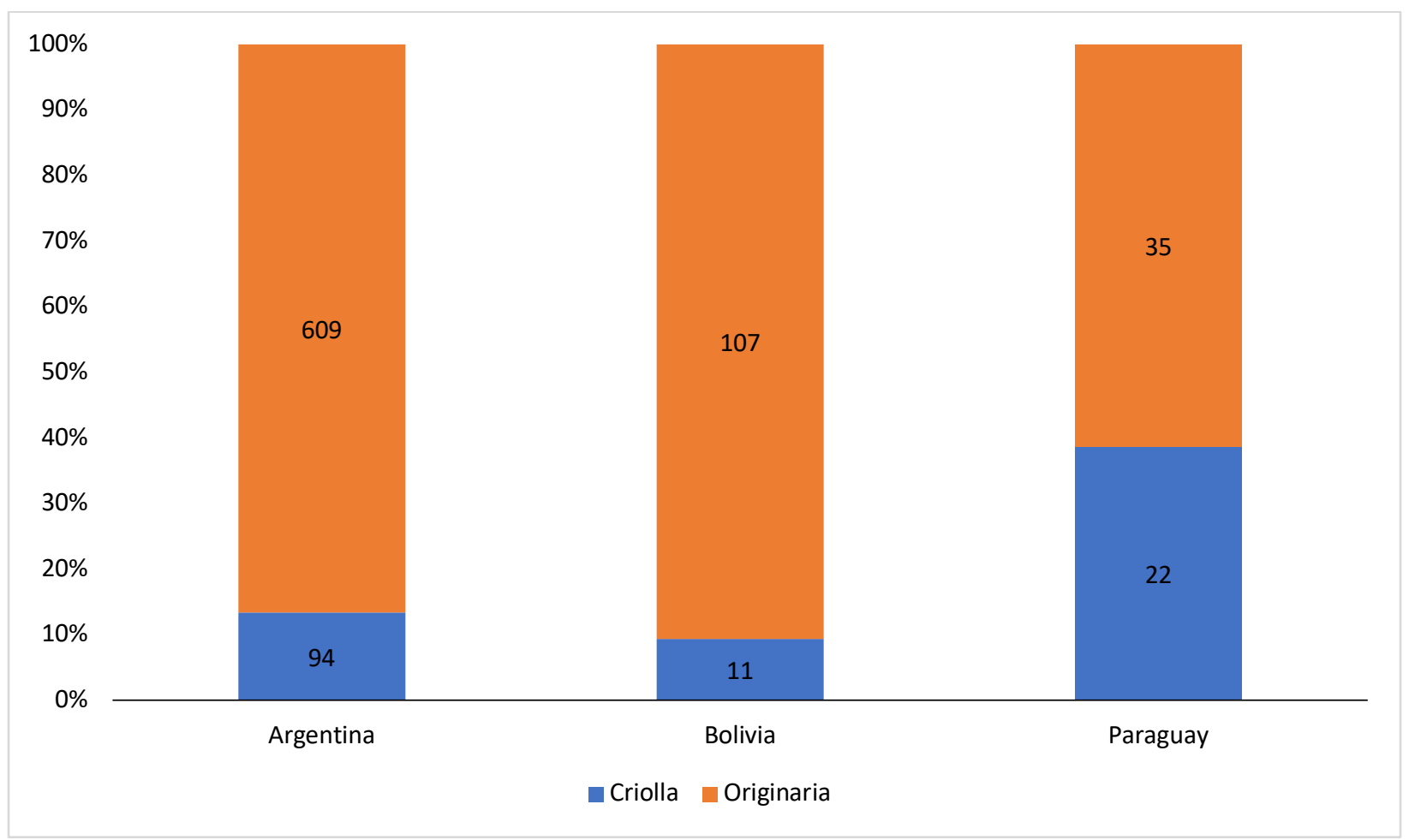

Note: Total prenatal women checked-up in 9 visits: 878 
Figure 5. Number of Pregnancies Prior to ADESAR/Mundo Sano prenatal checkup

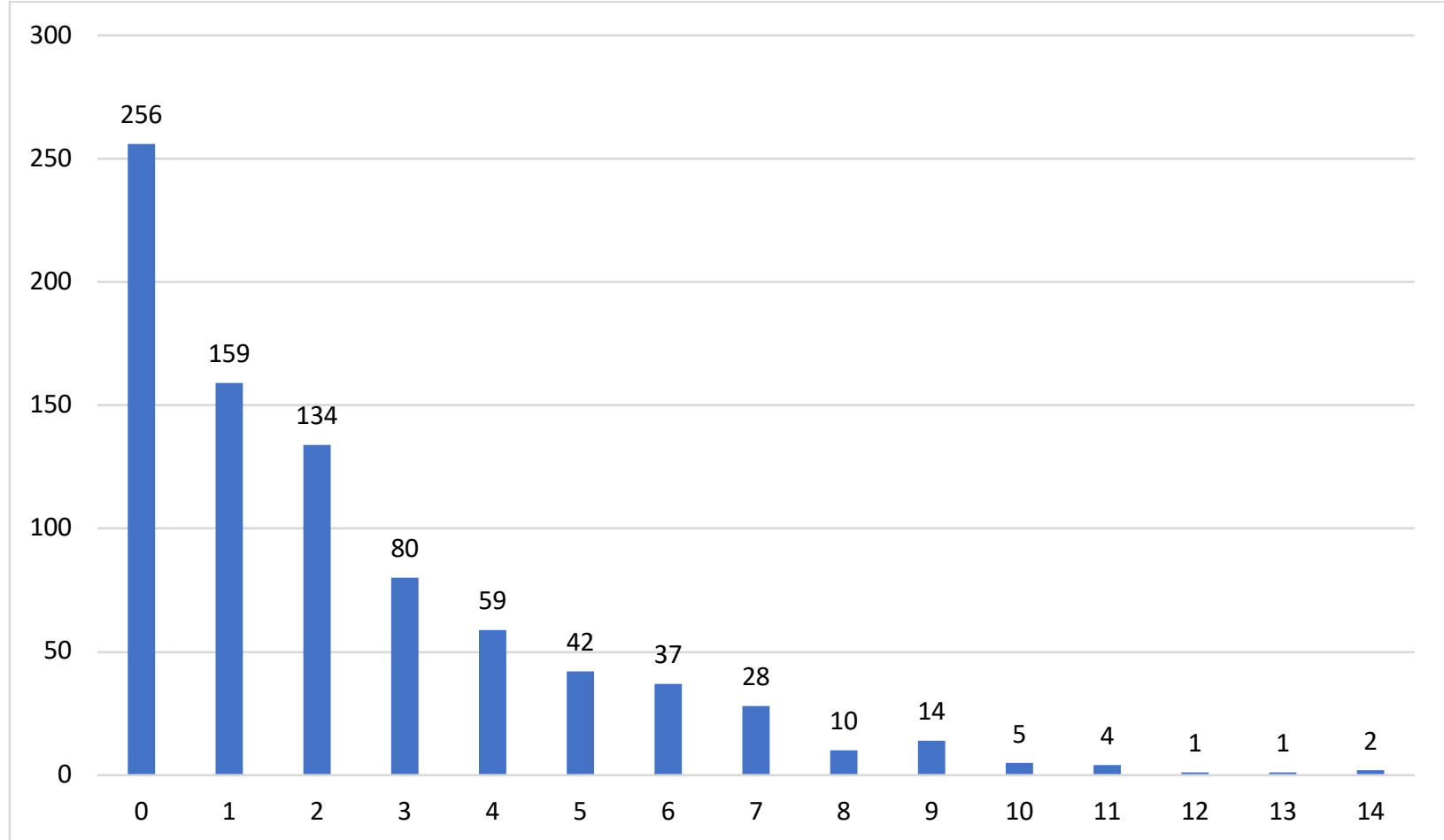

$\mathrm{N}=878$

Figure 6. Age at Women at First Pregnancy

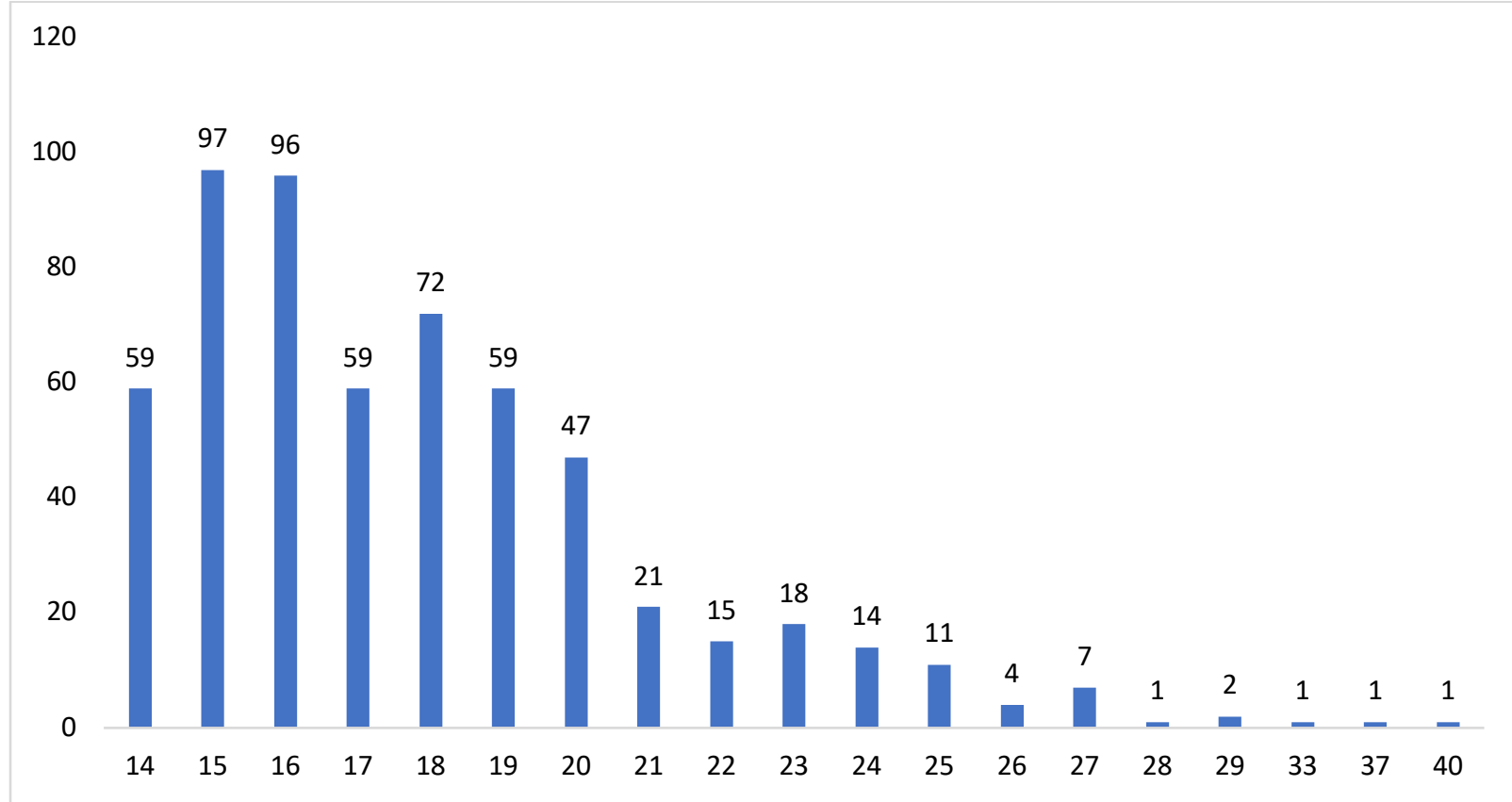

$\mathrm{N}=585$ 
Figure 7. Planned Pregnancy

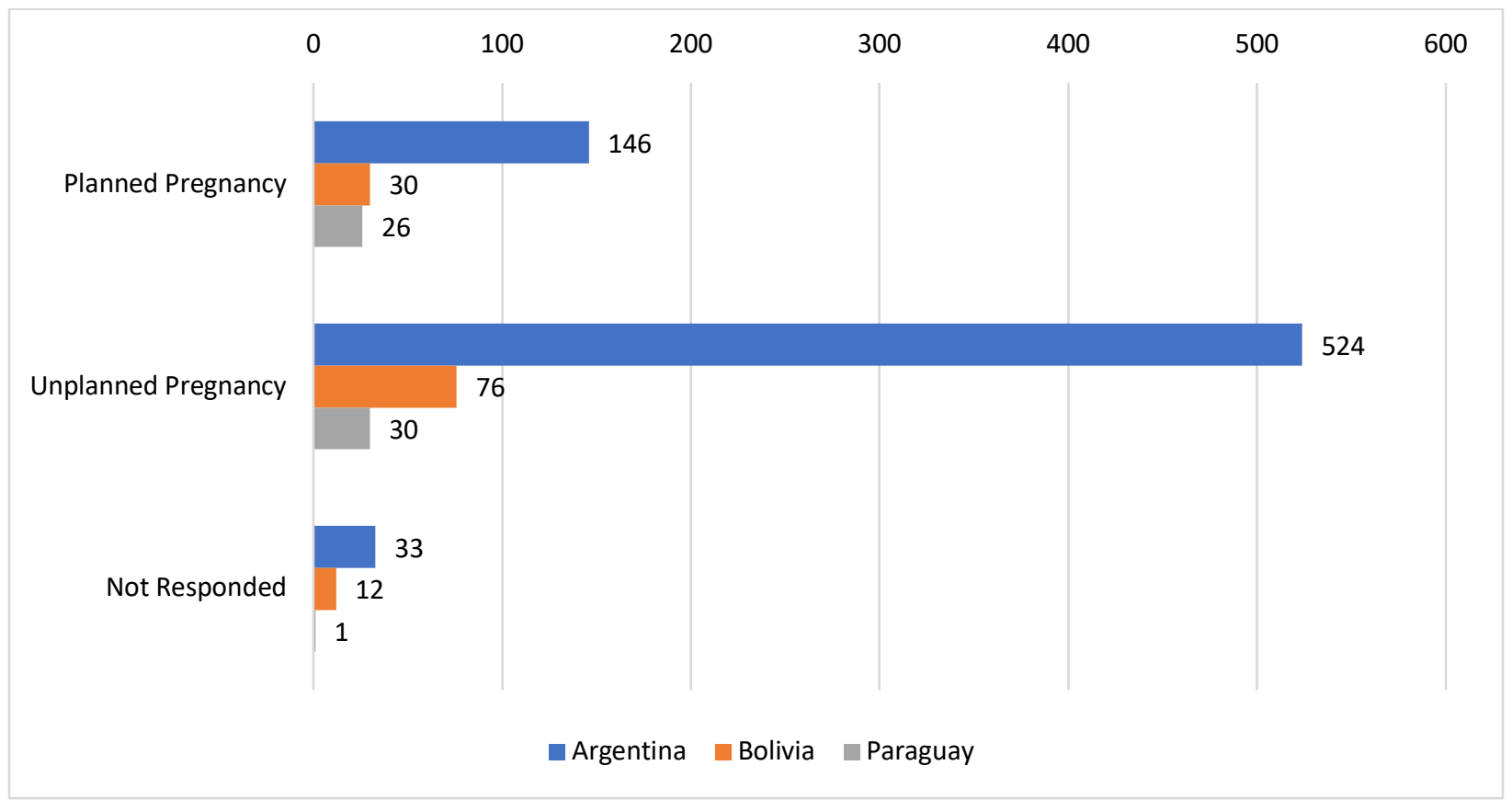

Table 2. In Depth Interviews with health care agents, by country and type of employment

\begin{tabular}{|c|c|c|c|c|c|}
\hline Country & Doctor & Nurse & $\begin{array}{c}\text { Sanitary } \\
\text { Agent }\end{array}$ & Other & Total \\
\hline Argentina & 4 & 5 & 6 & 6 & 21 \\
\hline Bolivia & 2 & 2 & $\mathbf{0}$ & $\mathbf{0}$ & 4 \\
\hline Paraguay & 1 & 2 & 0 & 0 & 3 \\
\hline Total & 7 & 9 & 6 & 6 & 28 \\
\hline
\end{tabular}


Table 3. Access to Health Care by Pregnant Women, ADESAR/Mundo Sano Intervention, tri-border of Great Chaco region, June 2018-October 2019.

- CAPTACION DE EMBARAZADAS (primer año)

\begin{tabular}{|c|c|c|c|c|}
\hline Lugar & Población & $\begin{array}{c}\text { Embarazos } \\
\text { estimados }\end{array}$ & $\begin{array}{c}\text { Embarazos } \\
\text { controlados PTF }\end{array}$ & $\begin{array}{c}\text { Porcentaje de embarazadas } \\
\text { estimadas captadas en PTF }\end{array}$ \\
\hline $\begin{array}{c}\text { Argentina } \\
\text { (SVE/AIS) }\end{array}$ & $\begin{array}{c}(13632 / 4000) \\
16571\end{array}$ & $\begin{array}{c}(341 / 51) \\
392\end{array}$ & $\begin{array}{c}(413 / 72) \\
485\end{array}$ & $123 \%$ \\
\hline Bolivia & 4038 & 140 & $79(2)(3)$ & $56,4 \%$ \\
\hline Paraguay & 2450 & 27 & $47(3)$ & $174,0 \%$ \\
\hline Total & 23059 & 559 & 611 & $109,3 \%$ \\
\hline
\end{tabular}

Población y Embarazos anuales estimados y cubiertos con al menos un control completo por PTF de junio 2018 a abril de 2019. (Incluye las cuatro serologías).

(2) No participó del primer operativo

(3) No se realizó 1 operativo por inundaciones

Source: ADESAR/Mundo Sano

Table 4. Hospital Derivations by ADESAR/Mundo Sano Intervention, tri-border of Great Chaco region, June 2018-October 2019.

\begin{tabular}{|c|c|}
\hline Cause of Hospital Derivation & Pregnant Women \\
\hline Pre-clampsia & 7 \\
\hline Dead fetus & 2 \\
\hline Severe Anemia & 3 \\
\hline Multiple pregnancies & 2 \\
\hline Diabetes & 8 \\
\hline Hypertension & 30 \\
\hline Total hospital derivations & 30 \\
\hline
\end{tabular}

Source: ADESAR/Mundo Sano 
Table 5. Pregnant women diagnosed with Chagas and Syphilis by ADESAR/Mundo Sano Intervention, tri-border of Great Chaco region, June 2018-October 2019.

\begin{tabular}{|c|c|c|c|c|c|c|c|c|}
\hline & \multicolumn{2}{|c|}{ ARGENTINA } & \multicolumn{2}{c|}{ BOLIVIA } & \multicolumn{2}{c|}{ PARAGUAY } & \multicolumn{2}{c|}{ TOTAL PTF } \\
\hline Controlled Pregnant Women & \multicolumn{2}{|c|}{720} & \multicolumn{2}{c|}{132} & \multicolumn{2}{c|}{63} & \multicolumn{2}{c|}{915} \\
\hline & $\mathrm{N}$ & $\%$ & $\mathrm{~N}$ & $\%$ & $\mathrm{~N}$ & $\%$ & $\mathrm{~N}$ & $\%$ \\
\hline CHAGAS & 37 & $5,1 \%$ & 30 & $22,7 \%$ & 2 & $3,17 \%$ & $\begin{array}{c}69 \\
\text { conf. }\end{array}$ & $7,54 \%$ \\
\hline SIFILIS & 5 & 0,69 & 0 & & 0 & & 5 & 0,54 \\
\hline VHB & 0 & & 0 & & 0 & & 0 & \\
\hline VIH & 0 & & 0 & & 0 & & 0 & \\
\hline
\end{tabular}

Source: ADESAR/Mundo Sano

Table 6. Total patients treated for Chagas, ADESAR/Mundo Sano Intervention, tri-border of Great Chaco region, June 2018 and until October 2019.

\begin{tabular}{|c|c|c|}
\hline & Total & Treated \\
\hline Puerpera w/Chagas & $\mathbf{2 6}$ & $\mathbf{1 3}$ \\
\hline New Borns w/Chagas & $\mathbf{3}$ & $\mathbf{3}$ \\
\hline Other Children w/Chagas & $\mathbf{8}$ & $\mathbf{7}$ \\
\hline Total patients w/Chagas treated & $\mathbf{3 7}$ & $\mathbf{2 3}$ \\
\hline
\end{tabular}

Note: In Argentina, all treatments were coordinated with the Dirección General de Coordinación Epidemiológica of the Ministry of Health of Salta.

Source: ADESAR/Mundo Sano 


\section{Figure 8. Coproduction Relationships, ADESAR/Mundo Sano Medical \\ Intervention, Great Chaco, 2018-2019}

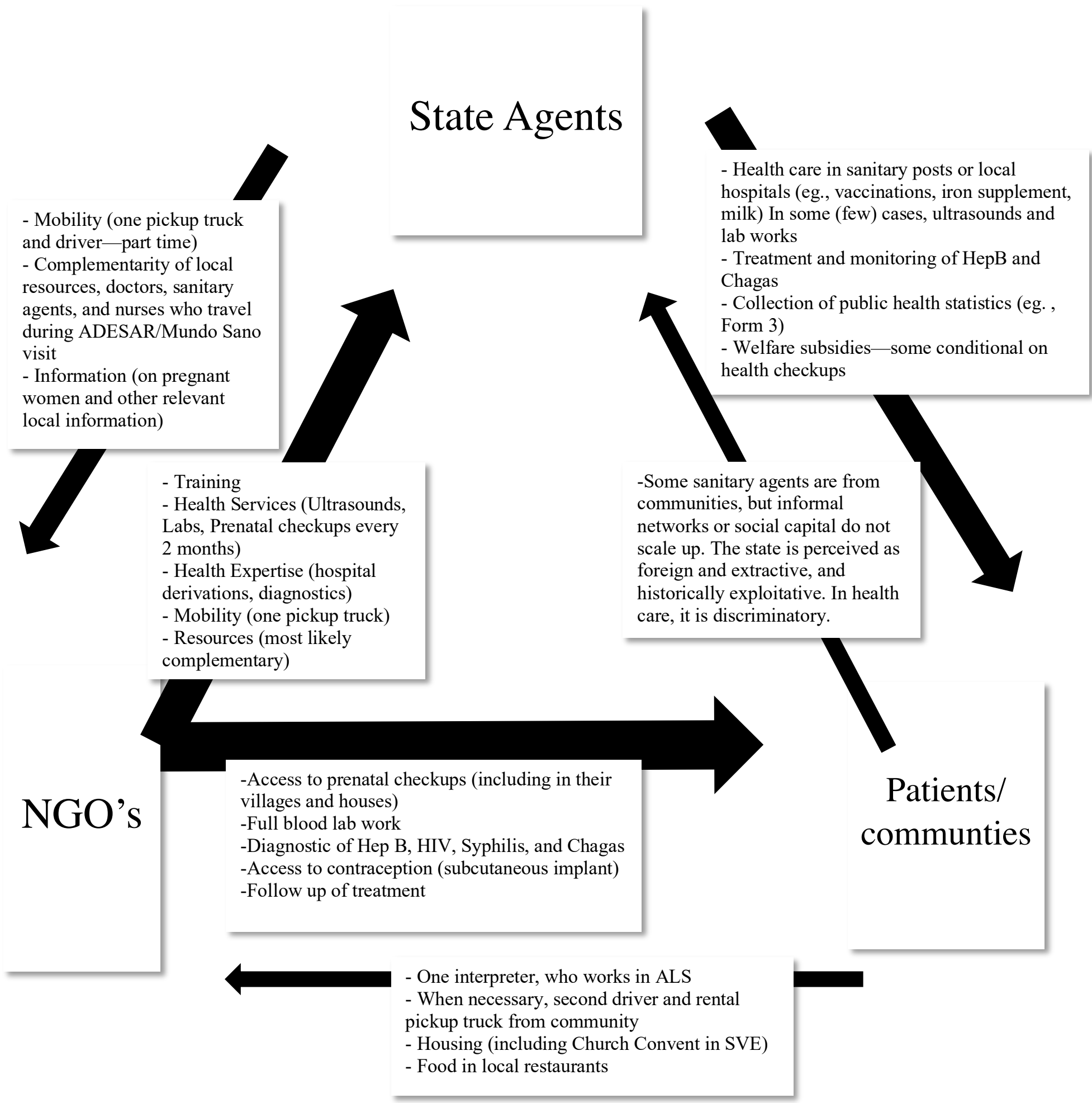


Figure A1. Surveyed Pregnant Women by Language they Speak at Home

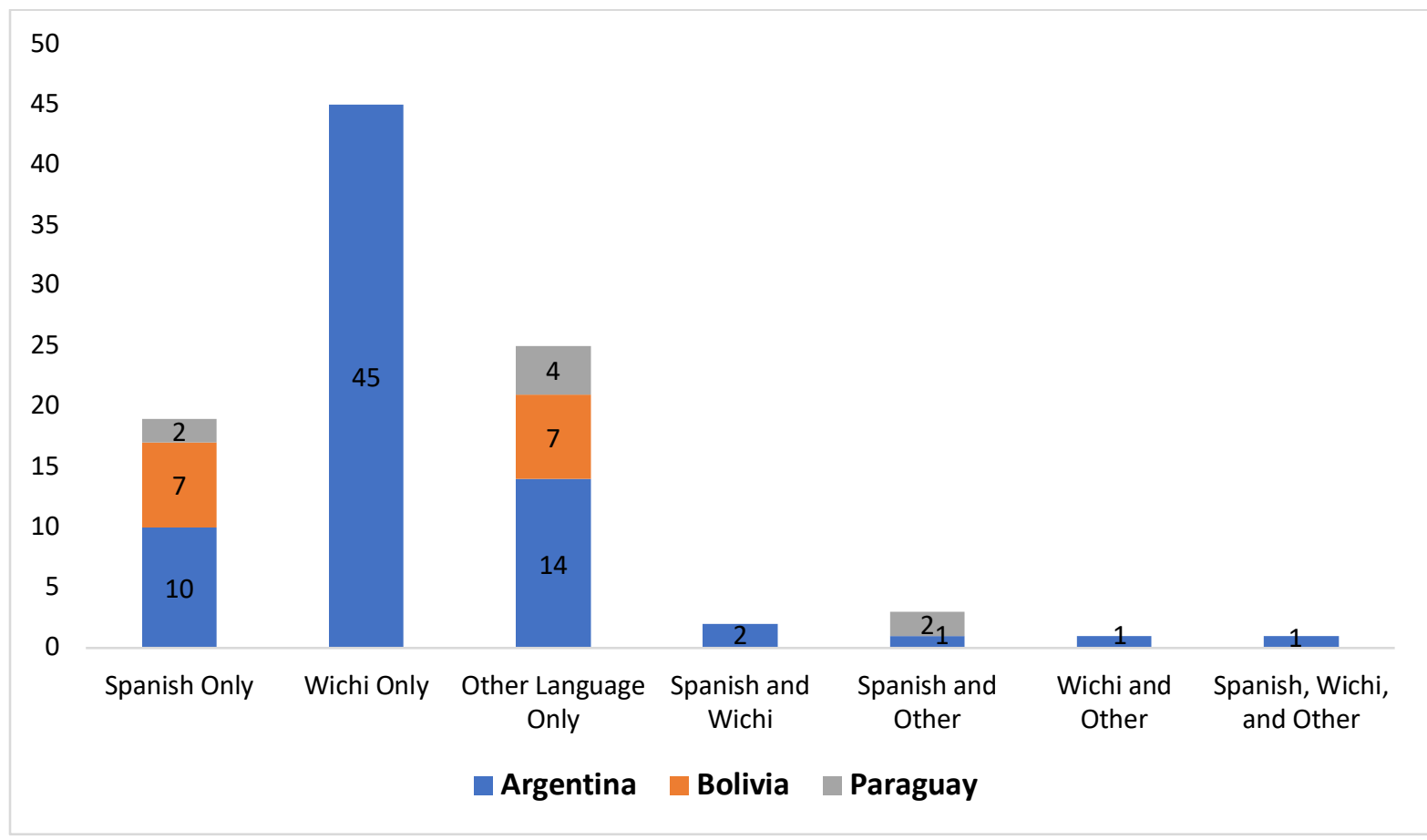

Figure A2. Surveyed Pregnant Women who are Recipients of Social Welfare Programs (by country)

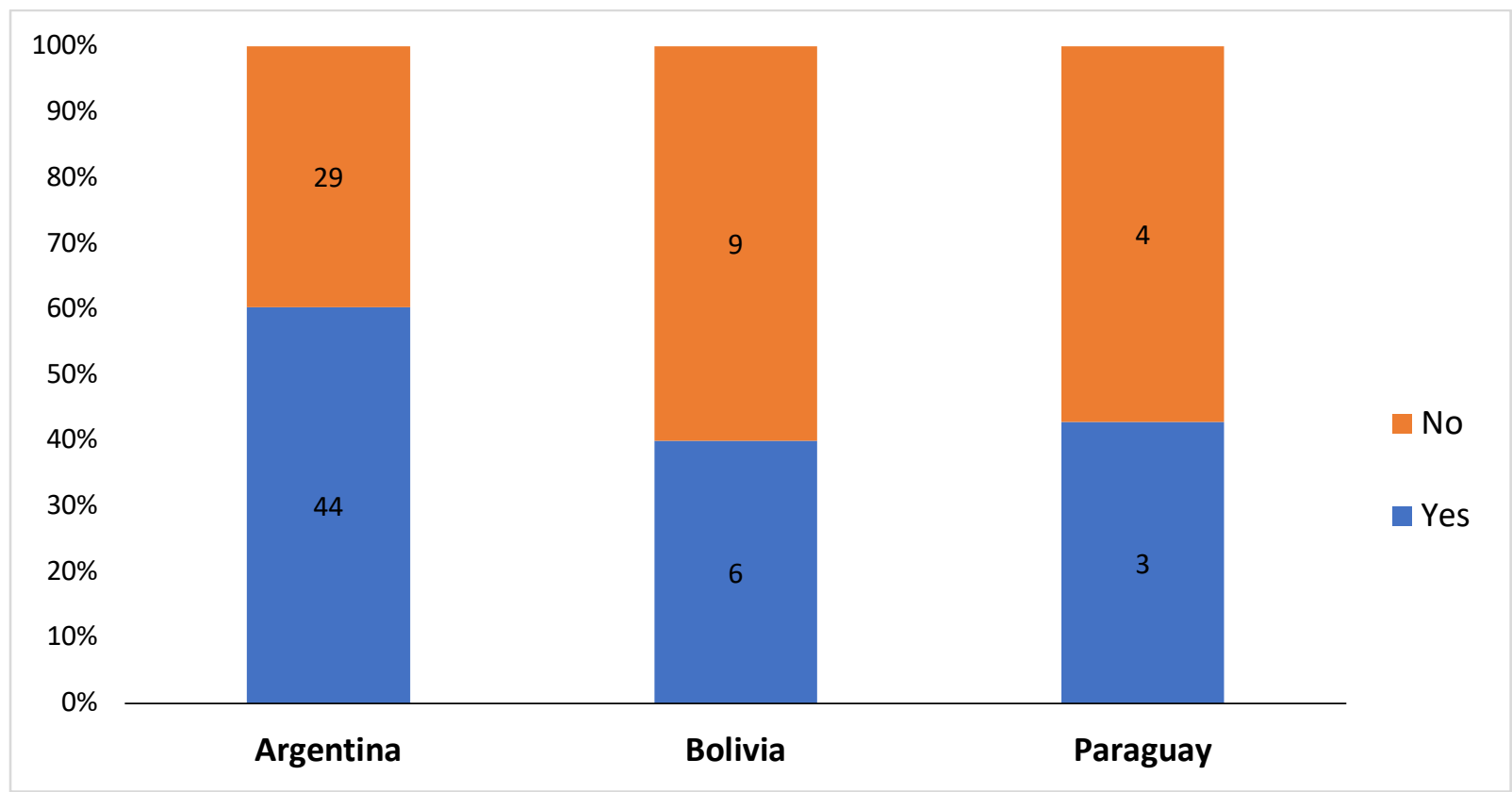


Figure A3. Surveyed Pregnant Women by Education Level and Country

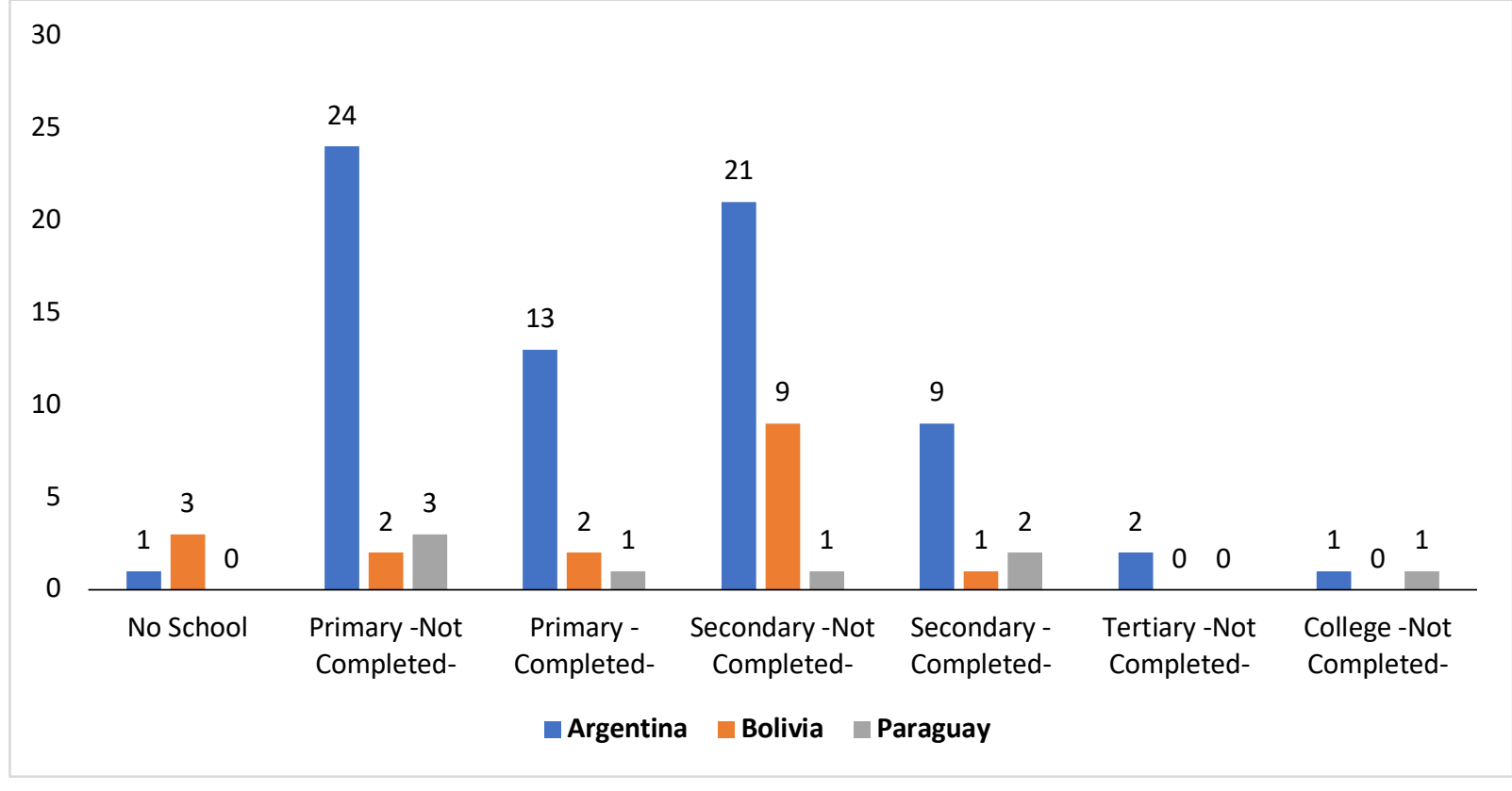

